\section{GENDER DIMENSIONS OF CLIMATE INSECURITY}

\section{ELIZABETH S. SMITH}

\section{Introduction}

Climate change and its implications for sustainable peace have been increasingly recognized in both academic work and policymaking, although it remains contested in both areas. ${ }^{1}$ Recent research has identified 'pathways' as a useful tool for conceptualizing the ways climate change may contribute to security risks (hereafter climate-related security risks). ${ }^{2}$ Climate change can indirectly increase the risk of conflict and insecurity through its influence on different intermediary factors. As identified by previous SIPRI research on East Africa, South and South East Asia, and West Africa, four known interrelated pathways are (a) worsening livelihood conditions, (b) increasing migration and changing mobility patterns, (c) tactical considerations by armed groups and (d) exploitation by elites and resource mismanagement. ${ }^{3}$ Gender is still a largely under-researched dimension in the climate-conflict context. ${ }^{4}$

For women and men, gender influences risks and agency related to the respective and compounding impacts of climate change and conflict. ${ }^{5}$ To

\footnotetext{
${ }^{1}$ Mobjörk, M., Krampe, F. and Tarif, K., 'Pathways of climate insecurity: Guidance for policymakers', SIPRI Policy Brief (Nov. 2020); Busby, J., 'Taking stock: The field of climate and security', Current Climate Change Reports, vol. 4, no. 4 (Dec. 2018); Scartozzi, C. M., 'Reframing climateinduced socio-environmental conflicts: A systematic review', International Studies Review, vol. 23, no. 3 (16 Aug. 2021); and United Nations and World Bank, Pathways for Peace:Inclusive Approaches to Preventing Violent Conflict (International Bank for Reconstruction and Development/World Bank: Washington, DC, 2018).

${ }^{2}$ Ide, T. et al., 'Multi-method evidence for when and how climate-related disasters contribute to armed conflict risk', Global Environmental Change, vol. 62 (May 2020); Mobjörk, Krampe and Tarif (note 1); van Baalen, S. and Mobjörk, M., A Coming Anarchy? Pathways from Climate Change to Violent Conflict in East Africa (Stockholm University: 2016); Busby, J., The Field of Climate and Security: A Scan of the Literature (Social Science Research Council: Apr. 2019); Meierding, E., 'Climate change and conflict: Avoiding small talk about the weather', International Studies Review, vol. 15, no. 2 (June 2013); Salehyan, I. and Gleditsch, K. S., 'Refugees and the spread of civil war', International Organization, vol. 60, no. 2 (2006); von Uexkull, N. et al., 'Civil conflict sensitivity to growing-season drought', Proceedings of the National Academy of Sciences, vol. 113, no. 44 (1 Nov. 2016); and von Uexkull, N. and Buhaug, H., 'Security implications of climate change: A decade of scientific progress', Journal of Peace Research, vol. 58, no. 1 (Jan. 2021).

${ }^{3}$ Mobjörk, Krampe and Tarif (note 1); Nordqvist, P. and Krampe, F., 'Climate change and violent conflict: Sparse evidence from South Asia and South East Asia', SIPRI Insights on Peace and Security no. 2018/4, Sep. 2018; van Baalen and Mobjörk (note 2); and Tarif, K., 'Climate change and violent conflict in West Africa: Assessing the evidence', SIPRI Insights on Peace and Security no. 2022/3, Feb. 2022.

${ }^{4}$ Ide, T. et al., 'Gender in the climate-conflict nexus: “Forgotten” variables, alternative securities, and hidden power dimensions', Politics and Governance, vol. 9, no. 4 (22 Oct. 2021).

${ }^{5}$ United Nations Environment Programme (UNEP), UN Women, UN Development Programme (UNDP), UN Department of Political Affairs and UN Peacebuilding Support Office, Gender, Climate and Security: Sustaining Inclusive Peace on the Frontlines of Climate Change (UNEP: Nairobi, 6 Nov.
}

\section{SUMMARY}

- Gender is a traditionally under-researched dimension in scholarship on climate and security. However, as recent research has noted, it is a variable that cannot only shape how different groups of individuals are affected by climate-related security risks. Gendered norms and power structures can also increase or mitigate the likelihood of climate-related security risks. This SIPRI Insights contributes to the growing body of research on gender, climate and security by analysing the gender dimensions of the four pathways of climate insecurity featured in past SIPRI studies: (a) livelihood deterioration, (b) migration and changing mobility, (c) tactical considerations of armed groups and $(d)$ elite exploitation and resource mismanagement. It reviews literature to highlight how gender can influence resilience and risk for different groups of men and women within the pathways. Where relevant, it also discusses how gender may serve as an instigating factor for the respective pathways. The paper stresses the need to critically understand the different and interlinked experiences of diverse groups of men and women in the pathway contexts and to ensure equal leadership and participation of all affected groups in addressing climaterelated security risks. 


\section{Box 1. Methodology}

This SIPRI Insights paper builds on existing SIPRI research on the pathways between climate change and violent conflict. Unlike prior SIPRI research on these pathways, this paper does not orient itself around a particular geography. ${ }^{a}$ This paper identified academic articles related to the four thematic areas of the pathways using keyword search method of abstracts and supplemented this selection with additional academic and grey literature. ${ }^{b}$ More specifically, Boolean search strings in two standard academic databases (Web of Science and ProQuest) were used to identify peer-reviewed literature. The report examines literature identified in the cross section between climate change, gender, conflict and the four respective pathway themes. While this provides insights into the gender dimensions of these four recognized pathways, the search strategy thus does not incorporate articles on the gender dimensions of other potential pathways, presenting a limitation of the scope of this research. Another limitation of this strategy is that it only includes articles written in English.

${ }^{a}$ van Baalen, S. and Mobjörk, M., A Coming Anarchy? Pathways from Climate Change to Violent Conflict in East Africa (Stockholm University, SIPRI and the Swedish Institute of International Affairs: 2016); Nordqvist, P. and Krampe, F., 'Climate change and violent conflict: Sparse evidence from South Asia and South East Asia', SIPRI Insights on Peace and Security no. 2018/4, Sep. 2018; and Tarif, K., 'Climate change and violent conflict in West Africa: Assessing the evidence', SIPRI Insights on Peace and Security no. 2022/3, Feb. 2022.

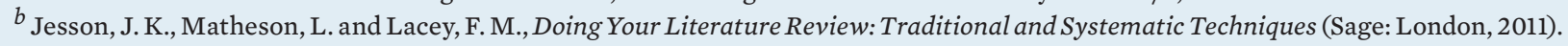

date, however, research on the pathways between climate change and conflict has focused primarily on violent conflict between groups on $s$ ales ranging from local to intrastate. ${ }^{6}$ This SIPRI Insights paper explores the gender dimensions of these four pathways. The different and interlinked experiences of women and men in the four pathway contexts underlines the need to ensure equal participation and leadership in addressing climaterelated security risks, as well as the importance of increasing the visibility of the needs of groups of people traditionally under-recognized in research and policy on gender, climate and security.

This Insights paper sheds light on how gender influences risk and resilience in relation to the four pathways. It focuses on male and female genders, as no relevant research on other gender identities was identified in the literature search on the four pathways (see box 1). Section II discusses gaps and concepts related to literature on gender, security and climate change. Section III discusses relevant findings to the gender dimensions of the four pathways. Section IV assesses findings against the pathway framework established by previous research focused on East Africa, South and South East Asia, and West Africa. Section V concludes the report with a discussion on ways forward.

\section{Gender and climate security: Gaps and concepts}

Research on and recognition of the nexus of gender, climate and security is developing. ${ }^{7}$ As recent research has noted, gender (see box 2) is a variable that

2020); and Smith, E. S., 'Climate change in Women, Peace and Security National Action Plans', SIPRI Insights on Peace and Security no. 2020/7, June 2020.

${ }^{6}$ Ide et al. (note 4); and Busby (note 1).

${ }^{7}$ Kronsell, A., 'WPS and climate change', eds S. E. Davies and J. True, The Oxford Handbook of Women, Peace, and Security (Oxford University Press: Oxford, 2019); Cohn, C. and Duncanson, C., 'Women, peace and security in a changing climate', International Feminist Journal of Politics, vol.22, no. 5 (19 Oct. 2020); Yoshida, K., Bond,H. and Kezie-Nwoha, H., Defendingthe Future:Gender, Conflict and Environmental Peace (LSE Centre for Women, Peace and Security: 2020); Yoshida, K. and Céspedes-Báez, L. M., 'The nature of women, peace and security: A Colombian perspective', International Affairs, vol. 97, no. 1 (11 Jan. 2021); UNEP (note 5); Ide et al. (note 4); Smith, J., Olosky, L. and Jennifer, G. F., The Climate-Gender Conflict Nexus Amplifying Women's Contributions at the Grassroots (Georgetown Institute for Women, Peace and Security: 2021); UN Security Council, 'Women, peace and security', Report of the UN Secretary-General, S/2021/827, 27 Sep. 2021; 
Box 2. Understanding gender

Gender can be defined as the learned 'social (rather than biological) attributes, norms, roles and attitudes' considered acceptable for people with varying sex characteristics in a certain society. ${ }^{a}$ Gender is not a fixed concept and changes according to the context and time period. ${ }^{b}$ Gender relations influence and uphold power dynamics between different groups of people, which can lead to different impacts and outcomes for various female, male, and non-binary gender identities in the same settings. ${ }^{c}$ Research indicates how norms, expectations and practices surrounding dominant, or 'hegemonic', forms of masculinity and their relationships to expectations of femininity can serve to legitimatize unequal relations between individuals of different and shared genders. ${ }^{d}$ Individuals experiencing gender inequalities can be further impacted in different ways due to overlapping forms of marginalization related to identity, including race, class, age, ethnicity, disability, sexual orientation or religion, among other factors. ${ }^{e}$

${ }^{a}$ United Nations Environment Programme (UNEP), UN Women, UN Development Programme (UNDP), UN Department of Political Affairs and UN Peacebuilding Support Office, Gender, Climate and Security: Sustaining Inclusive Peace on the Frontlines of Climate Change (UNEP: Nairobi, 6 Nov. 2020), p. 14; and Ide, T. et al., 'Gender in the climate-conflict nexus: "Forgotten" variables, alternative securities, and hidden power dimensions', Politics and Governance, vol. 9, no. 4 (22 Oct. 2021).

${ }^{b}$ United Nations Women, 'Gender equality glossary' (UN Women Training Centre: New York, 2019).

${ }^{c}$ Ide et al. (note a); and MacGregor, S., 'Only resist: Feminist ecological citizenship and the post-politics of climate change', Hypatia, vol. 29, no. 3 (2014).

${ }^{d}$ Messerschmidt, J. W., 'The salience of “hegemonic masculinity”', Men and Masculinities, vol. 22, no. 1 (Apr. 2019).

${ }^{e} \mathrm{UN}$ Committee on the Elimination of Discrimination Against Women, General Recommendation no. 37 on Gender related dimensions of disaster risk reduction in the context of climate change, CEDAW/C/GC/37, 7 Feb. 2018.

can influence both the occurrence and mitigation of climate-related security risks, and who is affected by these risks and how. ${ }^{8}$ Ignoring the relationship between gender, climate and security in work that is respectively focused on gender and security, and climate and security, may result in increased risks and inequalities for different groups of individuals. ${ }^{9}$ The following subsections discuss different relevant concepts and gaps in the literature and policy that address gender and security, and gender and climate.

\section{Gender and security}

Gendered norms and power structures influence the ways that different groups of men and women are affected by and participate in conflict, as well as their capacity to address it. Age, disability, socioeconomic class, sexual orientation and ethnicity are among the factors that further shape how individuals of different genders are affected by these dynamics. ${ }^{10}$ Examples of how gender shapes risks experienced by women and men in conflict, how they cope with or further insecurity and how conflict and insecurity are addressed are briefly discussed below.

\section{Sexual and gender-based violence}

In conflict settings, gender influences specific risks and violence faced by different groups of people. A common example of this is sexual and genderbased violence (SGBV) in conflict. SGBV has been used against women

Abdenur, A. et al., 'How can climate considerations be better integrated into the women, peace, and security agenda?', IPI Global Observatory, 2021; and George, N., 'Promoting women, peace and security in the Pacific Islands: Hot conflict/slow violence', Australian Journal of International Affairs, vol. 68, no. 3 (27 May 2014).

${ }^{8}$ Ide et al. (note 4$)$.

${ }^{9}$ UNEP (note 5).

${ }^{10}$ Coomaraswamy, R., Preventing Conflict, Transforming Justic, Securing the Peace: A Global Study on the Implementation of United Nations Security Council Resolution 1325 (UN Women: 2015); and World Bank and United Nations (note 1). 
and girls in conflict settings as a military tactic. ${ }^{11}$ Combatants in conflict perpetrate SGBV against female victims as a way to exert power and control. The broader intent is to humiliate the communities that women belong to and to underline to men in those communities that they have 'failed to protect "their" women'. ${ }^{12}$ SGBV in conflict is also perpetrated against males as a way to exert power and control. Combatants may perpetrate SGBV against male victims to negate the victims' individual power and status associated with masculinity and to harm their broader communities. ${ }^{13}$ For example, research conducted in 2010 in the South Kivu province of the Democratic Republic of the Congo-an area that experienced armed conflict for over decade-highlighted how SGBV perpetrated against men and boys led to severe trauma and shame for the survivors and their households and communities. Specifically, it created the perception that survivors were emasculated and led to the stigmatization of their family members. ${ }^{14}$

\section{Socioeconomic impacts of conflict}

Gender norms also influence how different individuals are affected by and cope with the socioeconomic impacts of armed conflict. ${ }^{15}$ Constrained or lack of control over necessary resources can lead to increased risks for women in conflict contexts. For example, in refugee or internally displaced persons (IDP) camps, where women rarely control necessary resources due to gender norms, they can be at heightened risk of SGBV and exploitation. Economic sanctions can lead to significant negative impacts for women in contexts where they are already more socioeconomically disadvantaged. ${ }^{16}$ However, despite challenges stemming from conflict and inequalities, women innovate and negotiate ways to cope with the effects of conflict and exercise agency in informal ways. ${ }^{17}$ Conflict can also bring about a shift in gendered norms and power relations, with consequences that can be both positive and challenging. For example, women responsible for providing for their households may take on the role of primary breadwinner, sometimes in vocations traditionally run by men, if male family members are absent, or limited in another way from engaging in the public sphere. ${ }^{18}$ While this can be empowering and lead to change in certain conditions, women in this

\footnotetext{
${ }^{11}$ Chinkin, C., 'Rape and sexual abuse of women in international law', European Journal of International Law, vol. 5 (1994); and Tickner, J. A., 'Peace and security from a feminist perspective', eds Davies and True (note 7).

12 Chinkin (note 11), p. 328.

${ }^{13}$ Sivakumaran, S., 'Sexual violence against men in armed conflict', European Journal of International Law, vol. 18, no. 2 (1 Apr. 2007).

${ }^{14}$ Christian, M. et al., 'Sexual and gender based violence against men in the Democratic Republic of Congo: Effects on survivors, their families and the community', Medicine, Conflict and Survival, vol. 27, no. 4 (Oct. 2011).

${ }^{15}$ UN Committee on the Elimination of Discrimination Against Women (CEDAW), General Recommendation no. 30 on Women in Conflict Prevention, Conflict and Post-Conflict Situations, CEDAW/C/GC/30, 1 Nov. 2013.

${ }^{16}$ Tickner (note 11$)$.

${ }^{17}$ El-Bushra, J., 'Transforming conflict: Some thoughts on a gendered understanding of conflict processes', eds S. Jacobs, R. Jacobson and J. Marchbank, States of Conflict, Gender, Violence and Resistance (Zed Books: London, 2000).

${ }^{18}$ CEDAW (note 15); and Leonardo, E. et al., 'Conflict-induced displacement as a catalyst for agricultural innovation: Findings from South Sudan', Land Use Policy, vol. 90 (Jan. 2020).
} 
position can face additional challenges if broader structures and ideologies do not shift along with gender roles. ${ }^{19}$

\section{Participation in peace processes}

Gender norms and power structures can also influence why and how men and women may participate in conflict as peacemakers or instigators of violence in different contexts. While men and women both play informal roles in peace processes and peacebuilding, gendered norms, stereotypes and power structures have contributed to sidelining women from actively participating in formal capacities. ${ }^{20}$ The absence of women in formal roles in peace processes is a definitive challenge for sustainable peace. Women's meaningful participation in peace processes has been noted to contribute to longer and more successful peace agreements. ${ }^{21}$ Research on numerous peace processes and agreements reveals that the meaningful inclusion of women in peace agreements results in agreements that are more likely to be reached and implemented, and more durable over time. ${ }^{22}$ Women's participation in creating policies and programmes addressing peace and security also increases the likelihood that they will address issues of direct concern for them. ${ }^{23}$ However, to date, women's formal participation in addressing these issues has been limited. From 1992 until 2019, women only accounted for 6 per cent of mediators and signatories of peace processes globally. ${ }^{24}$

\section{Participation in armed groups}

Men involved as actors in conflict are generally the main perpetrators of violence. ${ }^{25}$ However, research notes that men are not intrinsically violent, and the majority of them do not perpetrate violence. ${ }^{26}$ Research indicates that men may engage in violent conflict due to social, political and cultural expectations, or the economic inability to achieve ideals of non-violent masculinities, among other factors, across other potential rationales. ${ }^{27}$ Men may also be forcibly recruited as combatants. ${ }^{28}$ Women also engage in conflict as supporters of, or combatants in, armed groups and join, or are forced to join, for a number of reasons. For example, they may be forcibly recruited, or join to remove themselves from oppression and marginalization at home

\footnotetext{
${ }^{19}$ El-Bushra, J., 'Fused in combat: Gender relations and armed conflict', Development in Practice, vol.13, no. 2-3 (May 2003); El-Bushra, J. and Gardner, J., 'The impact of war on Somali men: Feminist analysis of masculinities and gender relations in a fragile context', Gender and Development, vol. 24, no. 3 (Sep. 2016); and Puechguirbal, N., 'Discourses on gender, patriarchy and Resolution 1325: A textual analysis of UN documents', International Peacekeeping, vol. 17, no. 2 (Apr. 2010).

${ }^{20}$ Coomaraswamy (note 10 ).

${ }^{21}$ World Bank and United Nations (note 1).

${ }^{22}$ Coomaraswamy (note 10); and O’Reilly, M., Ó Súilleabháin, A. and Paffenholz, T., Reimagining Peacemaking: Women's Roles in Peace Processes (International Peace Institute: 2015).

23 O'Reilly, M., 'Where the WPS pillars intersect', eds Davies and True (note 7).

${ }^{24}$ UN Women, 'Facts and figures: Women, peace, and security', accessed 10 Feb. 2022.

${ }^{25}$ Vess, J. et al., The Other Side of Gender Men as Critical Agents of Change (United States Institute of Peace: Washington, DC, 2013).

${ }^{26}$ World Bank and United Nations (note 1); and Vess et al (note 25).

${ }^{27}$ World Bank and United Nations (note 1); Bannon, I. and Correia, M. C. (eds), The Other Half of Gender (World Bank: Washington DC, 2006); Hudson, V. M. and Matfess, H., 'In plain sight: The neglected linkage between brideprice and violent conflict', International Security, vol. 42, no. 1 (July 2017); and Vess et al (note 25).

${ }^{28}$ Carpenter, R. C., 'Recognizing gender-based violence against civilian men and boys in conflict situations', Security Dialogue, vol. 37, no.1 (Mar. 2006).
} 
and gain different opportunities. Women may also contribute to violence by encouraging male relations to engage in conflict. ${ }^{29}$ Poverty and lack of access to necessary services are among the factors that influence both men and women to join armed groups. ${ }^{30}$

\section{Policy responses to gender and conflict}

The previous discussion provides non-exhaustive examples of the relationship between gender and conflict, focusing on male and female genders. However, despite the many different, overlapping and nuanced experiences of male and female genders in conflict-and how gender equality may contribute to preventing conflict-these dynamics are not comprehensively addressed in mainstream policy and frameworks aimed at gender, peace and security. The relationship between gender and security has gained increasing prominence on the international stage, notably since the United Nations Security Council adopted the first resolution of the women and peace and security (WPS) agenda in 2000. ${ }^{31}$ That resolution, UN Security Council Resolution 1325, has been followed by nine more resolutions that constitute the WPS agenda. The adoption of the WPS agenda marked an international recognition of the need to address gender-specific risks faced by women and girls in conflict and to promote the participation of women and girls in addressing peace and security issues. ${ }^{32}$ However, gender stereotypes still influence how women and men are understood and how their needs are responded to in relation to peace and security. Gender stereotypes are visible in UN rhetoric surrounding gender and conflict. ${ }^{33}$ Even after the uptake of the WPS agenda, 'gender' is often conflated with 'women'. The result is that women continue to be the primary focus in discussions surrounding gender and security. ${ }^{34}$ Women are often labelled as civilians, peacemakers and mothers and are associated with children-implicitly essentializing their roles in conflict and labelling them as a group of vulnerable people in need of protection. ${ }^{35}$ Less attention is paid to women as potential or actual combatants, or instigators of violence. ${ }^{36}$ Men's participation in violent conflict as combatants is arguably implicitly recognized as the status quo, with men and boys rarely and only vaguely mentioned throughout the WPS agenda resolutions. Of note is the comparatively higher focus on addressing SGBV perpetrated against men and boys in the ninth resolution, UN Security Council Resolution 2467. No explicit mention is directly made to other gender identities within the resolutions. ${ }^{37}$ The presumption that men act in certain roles during conflict-as combatants and perpetrators of violence, for

\footnotetext{
${ }^{29}$ El-bushra (note 17); and Rajivan, A. K. and Senarathne, R., Women in Armed Conflicts:Inclusion and Exclusion (UNDP: 2010).

${ }^{30}$ Rajivan and Senarathne (note 29).

${ }^{31}$ Coomaraswamy (note 10).

${ }^{32}$ Smith (note 5); George, N. and Shepherd, L. J., 'Women, peace and security: Exploring the implementation and integration of UNSCR 1325, International Political Science Review, vol. 37, no. 3 (June 2016).

${ }^{33}$ Shepherd,L.J., 'Sex, security and superhero(in)es: From 1325 to 1820 and beyond', International Feminist Journal of Politics, vol. 13, no. 4 (Dec. 2011); and Puechguirbal (note 19).

${ }^{34}$ Myrttinen, H., 'Locating masculinities in WPS', eds Davies and True (note 7).

${ }^{35}$ Puechguirbal (note 19).

${ }^{36}$ Puechguirbal (note 19).

${ }^{37}$ Myrttinen (note 34); UN Security Council Resolution 2467, S/RES/2467, 23 Apr. 2019; and UN Security Council Resolution 2493, S/RES/2493, 29 Oct. 2019.
} 
example-obscures their needs and vulnerabilities in conflict, their positive agency and how gendered norms influence them to act in relation to social expectations for men in their contexts. ${ }^{38}$

\section{Gender and climate}

Gendered norms and power structures influence the different ways various groups of individuals are affected by climate change and how they may respond to it. Age, disability, sexual orientation and socioeconomic class are among other variables that shape how different groups of men and women are affected by and adapt to climate change. ${ }^{39}$ Examples of how gender influences risks for women and men in different settings affected by climate change, how they respond to it and challenges in how research and policy address gender and climate are discussed below.

\section{Work and productivity}

Gender is among the variables that influence how people of different backgrounds may be affected by climate change. ${ }^{40}$ Gendered power structures shape the ability of different people to adapt to changing environmental circumstances and the risks they may experience. ${ }^{41}$ In contexts where women experience inequalities-including limited participation in decision making, limited access to information, productive and financial resources, among other factors, as well as constrained mobility-they can experience substantial risks adapting to or recovering from climatic changes. ${ }^{42}$ In contexts where women rely on natural resources for their livelihood, the impacts of climate change and environmental degradation can create additional and more extensive domestic burdens, as deteriorating environmental conditions increase the time and difficulty required to complete household tasks. ${ }^{43}$ These dynamics can not only challenge women's individual adaptation but that of their broader households and communities. Women in many different contexts play a primary role in ensuring household and national food security through their work with agriculture as well as forests and fisheries. ${ }^{44}$ In settings affected both by climate change and conflict,

\footnotetext{
${ }^{38}$ Myrttinen (note 34); and Vess et al (note 25).

${ }^{39}$ Carr, E. R. and Thompson, M. C., 'Gender and climate change adaptation in agrarian settings: Current thinking, new directions, and research frontiers: Gender and climate change adaptation in agrarian settings', Geography Compass, vol. 8, no. 3 (Mar. 2014).

${ }^{40}$ CEDAW, General Recommendation no. 37 on Gender-Related Dimensions of Disaster Risk Reduction in the Context of Climate Change, CEDAW/C/GC/37, 7 Feb. 2018.

${ }^{41}$ CEDAW (note 40 ).

42 Paudyal, B. R. et al., 'Gender integration in climate change and agricultural policies: The case of Nepal', Frontiers in Sustainable Food Systems, vol. 3 (23 Aug. 2019); Khatri-Chhetri, A. et al., 'Potential of climate-smart agriculture in reducing women farmers' drudgery in high climatic risk areas', Climatic Change, vol. 158, no. 1 (Jan. 2020); Carvajal-Escobar, Y., Quintero-Angel, M. and García-Vargas, M., 'Women's role in adapting to climate change and variability', Advances in Geosciences, vol. 14 (10 Apr. 2008); and CEDAW (note 40).

${ }^{43}$ Pearse, R., 'Gender and climate change', WIREs Climate Change, vol. 8, no. 2 (Mar. 2017); Kakota, T. et al., 'Gender vulnerability to climate variability and household food insecurity', Climate and Development, vol.3, no.4 (Oct. 2011); and Adhikari, S., 'Drought impact and adaptation strategies in the mid-hill farming system of Western Nepal', Environments, vol. 5, no. 9 (3 Sep. 2018).

${ }^{44}$ Agarwal, B., 'Gender equality, food security and the Sustainable Development Goals', Current Opinion in Environmental Sustainability, vol. 34 (Oct. 2018).
} 
women may face compounding risks, including a heightened risk of SGBV on increasingly lengthy journeys to collect natural resources. ${ }^{45}$

Gendered norms can also lead to risks for different groups of men in contexts affected by climate change. Climate change may impact the productivity of livelihoods dependent on natural resources and lead to loss of livelihood, land and assets for men. ${ }^{46}$ If changing environmental conditions affect economic conditions and subsequently men's ability to act as a provider in a household or community, this can contribute to psychological stress. Broader research demonstrates that male livelihood deterioration, related to environmental deterioration and/or conflict, results in negative impacts on men's wellbeing as well as local insecurity at times. ${ }^{47}$ For men who have traditionally depended on natural resource-based livelihoods, the impacts of environmental deterioration and/or conflict may detrimentally affect their identities and social relations and, in some cases, may contribute to domestic violence against their partners. ${ }^{48}$

\section{Migration and displacement}

Gender can influence the decision to migrate from or remain in contexts affected by climate change for different groups of women and men in complex ways. ${ }^{49}$ For men, research highlights that they often migrate away from their families in search of economic opportunities as a form of adaptation to slow-onset climate impacts and livelihood stress. Some research suggests they account for the majority of seasonal migration during periods of environmental stress in different contexts. ${ }^{50}$ Individual and community expectations surrounding masculine roles as family breadwinners can contribute to this, and men may face physical and psychological risks during

\footnotetext{
45 UNEP (note 5).

${ }^{46}$ Alston, M. and Whittenbury, K. (eds), Research, Action and Policy: Addressing the Gendered Impacts of Climate Change (Springer: New York, 2013).

${ }^{47}$ Ashamole, D. C., 'Extractive industry and the politics of manhood in Nigeria's Niger Delta: A masculinity perspective of gender implication of resource extractivism', NORMA, vol. 14, no. 4 (2 Oct. 2019); and El-Bushra and Gardner (note 19).

${ }^{48}$ Ashamole (note 47); El-Bushra and Gardner (note 19); Norgaard, K. M., Reed, R. and Bacon, J. M., 'How environmental decline restructures indigenous gender practices: What happens to Karuk masculinity when there are no fish?', Sociology of Race and Ethnicity, vol. 4, no. 1 (Jan. 2018); Lwambo, D., "Before the war, I was a man": Men and masculinities in the eastern Democratic Republic of Congo', Gender and Development, vol. 21, no.1 (Mar. 2013); and Whittenbury, K., 'Climate change, women's health, wellbeing and experiences of gender based violence in Australia', eds M. Alston and K. Whittenbury, Research, Action and Policy:Addressing the Gendered Impacts of Climate Change (Springer: 2013).

${ }^{49}$ Lama, P., Hamza, M. and Wester, M., 'Gendered dimensions of migration in relation to climate change', Climate and Development, vol. 13, no. 4 (21 Apr. 2021); and Pemberton, S. et al., "'Staying” as climate change adaptation strategy: A proposed research agenda', Geoforum, vol. 121 (May 2021).

${ }^{50}$ Knabe, F. and Nkoyok, J., 'Overcoming barriers: Promoting women's local knowledge', KM4D Journal, vol. 2, no. 1(2006); Leighton, M., 'Drought, desertification and migration: Past experiences, predicted impacts and human rights issues', eds E. Piguet, A. Pécoud and P. De Guchteneire, Migration and Climate Change (UNESCO: Cambridge, 2011); Massey, D. S., Axinn, W. G. and Ghimire, D. J., 'Environmental change and out-migration: Evidence from Nepal', Population and Environment, vol. 32, no. 2-3 (Dec. 2010); Myrttinen, H., 'The complex ties that bind: Gendered agency and expectations in conflict and climate change-related migration', Global Policy, vol. 8 (Feb. 2017); Pemberton (note 49); Silva Rodríguez de San Miguel, J. A., Martínez Díaz, E. and Monroy Becerril, D. M., 'The relationship between climate change and internal migration in the Americas', Management of Environmental Quality: An International Journal, vol. 32, no. 4 (22 June 2021); and Lama and Wester (note 49).
} 
migration. ${ }^{51}$ Male outmigration due to climate change can shift gender dynamics and impact those in the household who remain behind. ${ }^{52}$ Women become the heads of their households, which can in some cases increase their decision-making power and autonomy. In other cases, it increases their workload. ${ }^{53}$ In different contexts, women also migrate for economic reasons, but their migration patterns may vary from men's, with incentives for migration sometimes linked to their traditional roles. ${ }^{54}$ In certain contexts where women are responsible for gathering natural resources, women may be compelled to move further away to obtain necessary resources should they become scarce. ${ }^{55}$

For women in different contexts, gender can influence the voluntary or forced decisions to stay in contexts impacted by climate change. ${ }^{56}$ Gender norms and inequalities can lead to constraints around mobility and access to resources, as well as specific risks during migration for women. ${ }^{57}$ Research has often highlighted risks related to SGBV and exploitation faced by women and young girls when they migrate or are displaced. ${ }^{58}$ If female migrants faced constrained access to resources, this can lead to increased challenges in adapting to new environments, with some studies suggesting that they may be compelled to take low-paying jobs and put at risk of exploitation in different contexts. ${ }^{59}$ Gender also influences the adaptation strategies of men and women in climate-affected contexts where they do not leave. ${ }^{60}$ For example, in urban Manila, the Philippines, flooding is a regular occurrence. Both men and women often commute to work, but the combined impacts of flooding and gender norms shape their access to employment. ${ }^{61}$ While men may commute farther distances, women adapt to their environment by choosing to work closer to home. Public transport was generally seen negatively by women, who tended to choose other modes of transport including motorbikes modified to be used during flooding, or walking. ${ }^{62}$

\footnotetext{
${ }^{51}$ Detraz, N. and Windsor, L., 'Evaluating climate migration: Population movement, insecurity and gender', International Feminist Journal of Politics, vol. 16, no. 1 (2 Jan. 2014); and Terry, G., 'No climate justice without gender justice: An overview of the issues', Gender \& Development, vol. 17, no.1 (Mar. 2009).

52 Chindarkar, N., 'Gender and climate change-induced migration: Proposing a framework for analysis', Environmental Research Letters, vol. 7, no. 2 (1 June 2012).

53 Chindarkar (note 52).

${ }^{54}$ Myrttinen (note 50); and Detraz and Windsor (note 51).

55 Detraz and Windsor (note 51 ).

56 Pemberton (note 49 ).

${ }^{57}$ Chindarkar (note 52).

${ }^{58}$ Elnakib, S. et al., 'Drivers and consequences of child marriage in a context of protracted displacement: A qualitative study among Syrian refugees in Egypt', BMC Public Health, vol. 21, no. 1 (Dec. 2021); Kuehne, A. et al., 'Health of migrants, refugees and asylum seekers in detention in Tripoli, Libya, 2018-19: Retrospective analysis of routine medical programme data', PLOS ONE, vol. 16, no. 6 (4 June 2021); Ivanova, O., Rai, M. and Kemigisha, E., 'A systematic review of sexual and reproductive health knowledge, experiences and access to services among refugee, migrant and displaced girls and young women in Africa', International Journal of Environmental Research and Public Health, vol. 15, no. 8 (26 July 2018); and Lindvall, K. et al., 'Health status and health care needs of drought-related migrants in the Horn of Africa-a qualitative investigation', International Journal of Environmental Research and Public Health, vol. 17, no. 16 (14 Aug. 2020).

${ }^{59}$ Detraz and Windsor (note 51); and Chindarkar (note 52).

${ }^{60}$ Pemberton (note 49).

${ }^{61}$ Akyelken, N., 'Living with urban floods in metro Manila: A gender approach to mobilities, work and climatic events', Gender, Place \& Culture, vol. 27, no. 11 (1 Nov. 2020).

${ }^{62}$ Akyelken (note 61).
} 


\section{Natural disasters}

Gender norms and power structures can further influence the profound risks experienced by different groups of men and women in natural disaster and post-natural disaster contexts. ${ }^{63}$ For women, displacement due to natural disasters and/or violence can cause significant trauma and distress. ${ }^{64}$ In certain contexts, gendered norms and inequalities may limit women's access to information and resources and constrain their mobility. This can contribute to increased risks and, in some cases, increases the mortality rates for women in natural-disaster contexts. ${ }^{65}$ Natural disasters also contribute to psychological and physical vulnerabilities for men, who may risk their personal safety to take care of their households and communities per their expected roles as protectors. ${ }^{66}$ For men, displacement can undermine their traditional notions of masculinity, as they may feel unable to effectively protect and provide for their family members. ${ }^{67}$ Natural disasters also lead to severe trauma and grief for men. Research on international discourses on gender and post-natural disaster recovery in Sri Lanka suggests that severe trauma and grief for men are not consistently reflected upon and there is a tendency to focus on women's vulnerability and men's violence. ${ }^{68}$

In many contexts, women play a major role in helping their families and communities cope in natural disaster contexts. ${ }^{69}$ However, limited resources, traditional expectations of caregiving and constrained influence on formal decision making can challenge their ability to individually adapt to their circumstances and sustainably care for others. ${ }^{70}$ In their ascribed role as caregivers, women in post-natural disaster contexts may be compelled to take additional and unpaid compassionate roles to provide for the basic needs of others. ${ }^{71}$ Traditional gendered economic roles may also shift during displacement, as women continue their role providing food and water for their households at increased risk, while men experience sudden livelihood deprivation and related ramifications on their identity as heads

\footnotetext{
${ }^{63}$ Detraz, N. and Windsor, L. (note 51), 'Evaluating climate migration: Population movement, insecurity and gender', International Feminist Journal of Politics, vol. 16, no. 1 (2 Jan. 2014); and Enarson, E., Fothergill, A. and Peek, L., 'Gender and disaster: Foundations and directions', eds H. Rodríguez, W. Donner and J. E. Trainor, Handbook of Disaster Research (Springer: 2018).

${ }^{64}$ Swaroop, S. R. and DeLoach, C. D., 'Voices of trauma and resilience: Cultural and gender distinctive responses to war and displacement in Pakistan', Psychology and Developing Societies, vol. 27, no.1 (Mar. 2015).

${ }^{65}$ Kinnvall, C. and Rydström, H. (eds), Climate Hazards, Disasters, and Gender Ramifications (Routledge: Abingdon, 2019).

${ }^{66}$ Ide et al. (note 4); and Delaney, P. and Shrader, E., 'Gender and post-disaster reconstruction: The case of Hurricane Mitch in Honduras and Nicaragua', Decision Review Draft, World Bank, Jan. 2000.

${ }^{67}$ Hansson, S. and Kinvall,C., 'Disasters and gendered violence in Pakistan: Religion, nationalism and masculinity', eds Kinnvall and Rydström (note 65); and Anderson, J., ‘Gender, local justice, and ownership: Confronting masculinities and femininities in northern Uganda', The Canadian Journal of Peace and Conflict Studies, vol. 41, no. 2 (2009).

${ }^{68}$ de Alwis, M., 'The tsunami's wake Mourning and masculinity in Eastern Sri Lanka', eds E. Enarson and B. Pease, Men, Masculinities and Disaster (Routledge: Abingdon, 2016).

${ }^{69}$ Enarson, E., Fothergill, A. and Peek, L., 'Gender and disaster: Foundations and directions', eds H. Rodríguez, W. Donner and J. E. Trainor, Handbook of Disaster Research (Springer: 2018).

${ }^{70}$ Enarson, Fothergill and Peek (note 69); and Hansson and Kinvall (note 67).

${ }^{71}$ Tanyag, M. and True, J., 'Gender responsive alternatives on climate change from a feminist standpoint', eds Kinnvall and Rydström (note 65); and Tanyag, M., 'Resilience, female altruism, and bodily autonomy: Disaster-induced displacement in post-Haiyan Philippines', Signs: Journal of Women in Culture and Society, vol. 43, no. 3 (Mar. 2018).
} 
of households. ${ }^{72}$ Breakdowns in normal social formations in the wake of disasters can also contribute to increased domestic violence against women in different cases, which research suggests is due to an effort of men to maintain status quo hierarchies of power. ${ }^{73}$ In certain disaster contexts, women-especially female heads of households-may be marginalized from receiving necessary assistance, information, or shelter and other recovery resources. In some cases, sociocultural norms may impact women's mobility to seek shelter or assistance in times of disaster. ${ }^{74}$ Women can experience increased domestic burdens and increased risks carrying them out in the aftermath of natural disasters. ${ }^{75}$ Post-natural disaster, daily tasks including gathering water and other resources can become more challenging and time consuming. ${ }^{76}$ Research on women in Sri Lanka displaced by the 2004 tsunami suggests women's strategies and capacities to adjust to the postdisaster context was shaped by their different backgrounds and previous exposure to displacement; it also notes that forms of income generation available to women were primarily informal and homebound, reinforcing the gender inequalities that existed prior to the tsunami. ${ }^{77}$

\section{Adaptation strategies}

Gendered norms and power structures can also influence adaptation strategies. While gender inequalities may constrain women's access to resources, formal decision making, and information among other factors, research substantiates that different groups of women consistently innovate new ways to adapt to climate change impacts. For example, in different contexts, women have mobilized their communities to adapt to climate impacts and manage risks. They have established networks with other women to increase the social capital needed to address risks. ${ }^{78}$ They also negotiate around the structures that can serve to marginalize them. ${ }^{79}$ For example, when communities in Malawi's Lake Chilwa basin experience stakeholder disputes over scarce access to water, women are often significantly affected due to having strictly limited access and control over water. However, to assert control over access to water, they have leaned on traditional 'feminine'

\footnotetext{
${ }^{72}$ Anderson (note 67).

${ }^{73}$ Austin, D., 'Hyper-masculinity and disaster: The reconstruction of hegemonic masculinity in the wake of calamity', eds E. Enarson and B. Pease, Men, Masculinities and Disaster (Routledge: Abingdon, 2016).

${ }^{74}$ Hansson and Kinvall (note 67); Raju, E., 'Gender as fundamental to climate change adaptation and disaster risk reduction experiences from South Asia', eds Kinnvall and Rydström (note 65); and Sultana, F., 'Gendering climate change: Geographical insights', Professional Geographer, vol. 66, no. 3 (2014).

75 Tanyag (note 71); and Chindarkar (note 52).

${ }^{76}$ Hayward, G. and Ayeb-Karlsson, S., "'Seeing with empty eyes": A systems approach to understand climate change and mental health in Bangladesh', Climatic Change, vol.165, no.1-2 (Mar. 2021).

${ }^{77}$ Ruwanpura, K. N., 'Temporality of disasters: The politics of women's livelihoods "after” the 2004 tsunami in Sri Lanka', Singapore Journal of Tropical Geography, vol. 29, no. 3 (Nov. 2008).

${ }^{78}$ Carr, E. R. and Thompson, M. C., 'Gender and climate change adaptation in agrarian settings: Current thinking, new directions, and research frontiers', Geography Compass, vol. 8, no. 3 (Mar. 2014); Carvajal-Escobar, Quintero-Angel and García-Vargas (note 42). Sultana, F., 'Gendering climate change: Geographical insights', Professional Geographer, vol. 66, no. 3 (2014); and Whyte, K. P., 'Indigenous women, climate change impacts, and collective action', Hypatia, vol. 29, no. 3 (2014).

${ }^{79}$ Khadiagala, L. S., 'Justice and power in the adjudication of women's property rights in Uganda', Africa Today, vol. 49, no. 2 (2002); and Nkhoma, B. and Kayira, G., 'Gender and power contestations over water use in irrigation schemes: Lessons from the lake Chilwa basin', Physics and Chemistry of the Earth, Parts A/B/C, vol. 92 (Apr. 2016).
} 
farming activities including the farming of certain crops during different seasons, allowing them to use and control water in irrigation schemes. ${ }^{80}$

In their social roles, which may include household and community caregiving roles, or through their livelihood activities tied to natural resources, different groups of women can often be in excellent positions to understand community needs and recognize and address changes in their environments. ${ }^{81}$ Like conflict, climate change can bring about changes and shifts in gender roles and dynamics. The deterioration of natural resources as a primary source of income can impact the individual livelihoods and roles of men and women in different and interlinked ways. ${ }^{82}$ For example, in situations where men may migrate away from their households to find economic opportunities, women may take on economic and decision-making roles-traditionally held by men-in addition to their own roles. Shifting economic circumstances can impact understandings of what it means to be a man or a woman and how related responsibilities may be performed. ${ }^{83}$ While this can lead to positive shifts in some cases, women can encounter increased workloads without necessarily increasing their income and formal decisionmaking power if broader traditional structures do not change. ${ }^{84}$

\section{Representation in climate change governance}

Despite women's consistent and important role in building resilience and adapting to climate change, they are often marginalized from formal decision making on multiple levels. On national and global levels, women's formal participation in climate change governance has been low. ${ }^{55} \mathrm{On}$ a global scale, women have been under represented as formal negotiators at the 1992 United Nations Framework Convention on Climate Change (UNFCCC) Conference of the Parties (COP) conferences, which is also arguably reflective of their representation at regional and national levels, as many top negotiators are also leaders in environmental decision making in their home countries. ${ }^{86}$ Data from 2015 highlighted that, of the 881 national ministries addressing environmental sectors across 193 UN members states, only 12 per cent had female ministers. ${ }^{87}$ As of 2020,15 per cent of 712 environ-

\footnotetext{
${ }^{80}$ Nkhoma and Kayira (note 79).

${ }^{81}$ Carvajal-Escobar, Quintero-Angel and García-Vargas (note 42); Tanyag and True (note 71); Dunn, H. and Matthew, R., 'Natural resources and gender in conflict settings', Peace Review, vol. 27, no. 2 (3 Apr. 2015); Smith (note 5); and Kassam, K.-A., 'Viewing change through the prism of indigenous human ecology: Findings from the Afghan and Tajik Pamirs', Human Ecology, vol. 37, no. 6 (Dec. 2009).

${ }^{82} \mathrm{Lau}, \mathrm{J}$. D. et al., 'Gender equality in climate policy and practice hindered by assumptions', Nature Climate Change, vol. 11, no. 3 (Mar. 2021).

${ }^{83}$ Berckmoes, L. and White, B.,'Youth, farming, and precarityin rural Burundi', ed. R. Huijsmans, Generationing Development: A Relational Approach to Children, Youth and Development (Palgrave Macmillan: London, 2016); Floro, M. S., 'The crises of environment and social reproduction: Understanding their linkages', Journal of Gender Studies, vol. 15 (2012); Herrera, G., 'Starting over again? Crisis, gender, and social reproduction among Ecuadorian migrants in Spain', Feminist Economics, vol. 18, no. 2 (Apr. 2012); and Ashamole (note 47).

${ }^{84}$ Djoudi, H. and Brockhaus, M., 'Is adaptation to climate change gender neutral? Lessons from communities dependent on livestock and forests in northern Mali', International Forestry Review, vol. 13, no. 2 (1 June 2011).

${ }^{85}$ Tanyag and True (note 71$)$.

${ }^{86}$ Tanyag and True (note 71 ).

${ }^{87}$ International Union for Conservation of Nature (IUCN) and UN Women, 'Women's participation in global environmental decision making', Aug. 2015, p. 3.
} 
mental sector ministries across 187 countries were run by women. ${ }^{88}$ Women also comparatively account for larger parts of non-governmental organization (NGO) delegations and participate in informal discussions at the COP conferences. ${ }^{89}$ As of 2015 , women accounted for approximately 45 per cent of NGO representatives at the 2014 UNFCCC COP 20. In contrast, their representation among government delegates averaged to 36 per cent. ${ }^{90}$

However, the focus on gender and formal representation of women at the UNFCCC COPs has increased in recent years. As of 2020, women accounted for 40 per cent of party delegations and 27 per cent of heads and deputy heads of delegations. ${ }^{91}$ In 2017, the UNFCCC adopted its first Gender Action Plan, which pushed for gender-responsive climate policy and action, as well as women's participation as decision makers in climate policy. This plan was renewed and updated in 2019. ${ }^{92}$ In the UNFCCC's 2019 Gender Action Plan, there are no direct mentions made to critically understanding and addressing the needs and experiences of men and boys or other gender identities, aside from a mention of the need to 'strengthen the evidence base and understanding of the differentiated impacts of climate change on men and women'. ${ }^{93}$

\section{Gender and climate security}

Gender has often been absent from both policy and research on climate and security, despite being a factor that can contribute to influencing or mitigating the likelihood of climate-related security risks, as well as shaping risks faced by different groups of individuals in settings affected by the compound impacts of climate change and insecurity. ${ }^{94}$ Concepts discussed above from respective literature on gender and security, and gender and climate, highlight a number of similar trends. Women play crucial roles in addressing peace and security, and climate change, but they are also often marginalized from equal representation in formal decision making. Gender influences how both men and women of different backgrounds are affected by climate change and conflict, but specific gendered risks faced by men may receive comparatively less acknowledgement in major frameworks addressing gender, peace and security, or gender and climate change. Climate change and conflict both contribute to contexts that can affect and shift gender norms and dynamics, which can lead to both positive as well as difficult consequences for women and can challenge traditional understandings of masculinity for men.

\footnotetext{
${ }^{88} \mathrm{IUCN}$, 'New data reveals slow progress in achieving gender equality in environmental decision making', 1 Mar. 2021.

89 Tanyag and True (note 71).

${ }^{90}$ IUCN (note 88).

${ }^{91}$ UN Framework Convention on Climate Change (UNFCCC), Conference of the Parties, 'Gender Composition Report by the Secretariat', FCCC/CP/2020/3, 7 Oct. 2020.

92 Huyer, S. et al., 'Can we turn the tide? Confronting gender inequality in climate policy', Gender \& Development, vol. 28, no. 3 (1 Sep. 2020); UNEP (note 5); and Smith, Olosky and Grossman Fernandez (note 7).

${ }^{93}$ UNFCCC, Conference of the Parties, 'Report of the Conference of the Parties on its twentyfifth session', FCCC/CP/2019/13/Add.1,16 Mar. 2020, p. 10.

${ }^{94}$ Ide et al. (note 4); and UNEP (note 5).
} 


\section{Climate insecurity pathways}

Previous SIPRI research on pathways between climate change and conflict identified four indirect mechanisms: (a) livelihood deterioration, (b) migration and changing mobility, (c) tactical considerations and (d) elite exploitation. The following subsections add to the growing literature on gender, climate and security. They provide case study examples that discuss how gender affects different risks experienced by different groups of men and women within the pathways, how gender influences the way that men and women cope with the impacts of the pathways, and how gender may act as a factor influencing the likelihood of climate-related security risks.

\section{Livelihood deterioration}

Prior research on pathways between climate change to violent conflict has found that livelihood deterioration can contribute to an increased risk of conflict. For example, the negative impacts of climate change on livelihoods that are dependent on natural resources can contribute to increased marginalization and related grievances. ${ }^{95}$ There is an observed higher risk that people may use violence or join armed movements to ensure access to scarce resources. ${ }^{96}$ Research also suggests that sudden-onset disasters and slow-onset degradation can increase communal tensions and competition over diminishing resources.${ }^{97}$ Case studies on different groups of women in Western Sudan (pre-2011); Kenya; Somalia; Liberia; Colombian Caribbean; the Philippines; the Pamir Mountains between Tajikistan and Afghanistan; and Ethiopia demonstrate how in contexts of insecurity and climate change, gender influences how women face problems related to livelihood deterioration but consistently find ways to adapt to their circumstances, albeit not without challenges. Cases also demonstrate that risks and coping measures experienced and implemented by women vary by geography and social group. Men receive comparatively less focus within the studies. Within different case studies discussed below, men's migration as a way of coping with changing circumstances was highlighted, as well as severe stress felt on account of changing gender roles.

\section{Livelihood deterioration, insecurity and gendered risks and resilience}

A study on Western Sudan, a region affected both by droughts and conflict, discusses how female farmers play a major part in household food production and procurement. They spend most of their earnings on providing food for their family. However, gendered biases, inequalities and disenfranchisement from accessing necessary farming resources (seeds, credit, technologies, marketing etc.) can affect their ability to productively farm, impacting the

\footnotetext{
95 Mobjörk, Krampe and Tarif (note 1).

${ }^{96}$ Nordqvist and Krampe (note 3); Axbard, S., 'Income opportunities and sea piracy in Indonesia: Evidence from satellite data', American Economic Journal: Applied Economics, vol. 8, no. 2 (1 Apr. 2016); Vanden Eynde, O., 'Targets of violence: Evidence from India's naxalite conflict', The Economic Journal, vol. 128, no. 609 (1 Mar. 2018); and Mobjörk, Krampe and Tarif (note 1).

${ }^{97}$ Barnett, J. and Adger, W. N., 'Climate change, human security and violent conflict', Political Geography, vol. 26, no. 6 (2007); van Baalen, S. and Mobjörk, M., 'Climate change and violent conflict in East Africa: Integrating qualitative and quantitative research to probe the mechanisms', International Studies Review, vol. 20, no. 4 (1 Dec. 2018); and Mobjörk, Krampe and Tarif (note 1).
} 
yields of certain crops over time. This can increase challenges in providing for their households when they take on the position as main breadwinner. The study noted conflict and drought as factors that influence male family members to migrate in search of employment. Women who remain at home and work in agriculture take on the responsibility of the household decision maker in the absence of their male counterparts. While to their lack of ability to access credit and other economic resources impedes food production, research shows that women use short- and long-term coping strategies to deal with livelihood stress. In the short-term, they change their consumption practices to ensure household survival, relying on indigenous knowledge to process wild products and improve the nutritional value of accessible food. They also depend significantly on their social networks to share knowledge and agricultural inputs. These tactics help them to diversify income sources and manage the impacts of livelihood loss. ${ }^{98}$ In the long-term, they switch to cultivation of drought-resistant crops, use intercropping and mixed farming to mitigate the risk of total crop failure in the event of low rainfall and rely on indigenous knowledge to assist with pest control and water purification, among other strategies. Livelihoods are also supplemented through diversification into petty trade. ${ }^{99}$

Research on different pastoralist communities in Kenya highlights gendered challenges faced by female pastoralists and ways in which they adapt to and cope with the overlapping risks posed by climate change, insecurity and marginalization. In the Turkana region of Kenya, women in pastoral communities play a crucial role in ensuring the food security of their households, especially as cattle herds diminish and they must diversify their livelihood activities. However, women, especially female-headed households, can experience significant risks. As women have limited customary rights to natural and economic resources, they are left at a heightened risk of poverty and displacement should they lose male family members in conflict. ${ }^{100}$ Other research on pastoralist communities in Lake Turkana notes that climate change and conflict have compelled groups to diversify livelihood activities, including fishing. Women participated in fishing-a traditionally male-dominated livelihood activity-along with men, representing a shift from their gendered traditional livelihood responsibilities. Women involved in fishing have been noted to sell their fish to other women whose boats had a smaller catch. ${ }^{101}$ Other research on pastoralist groups in Kenya's drylands notes how low-income women diversify livelihoods through the collection of gums and resins including hagar and frankincense. ${ }^{102}$

A study on pastoralist women in northern Kenya finds that pastoral women created collective action groups to improve the quality of life for group members in a context affected by drought, environmental degradation and

\footnotetext{
${ }^{98}$ Ibnouf, F. O., 'Challenges and possibilities for achieving household food security in the Western Sudan region: The role of female farmers', Food Security, vol. 3, no. 2 (June 2011).

${ }^{99}$ Ibnouf (note 98 ).

100 Omolo, N., 'Gender and climate change-induced conflict in pastoral communities: Case study of Turkana in Northwestern Kenya', African Journal on Conflict Resolution, vol. 10 (2010).

${ }^{101}$ Yongo, E. O., Abila, R. O. and Lwenya, C., 'Emerging resource use conflicts between Kenyan fishermen, pastoralists and tribesmen of Lake Turkana', Aquatic Ecosystem Health \& Management, vol. 13, no. 1 (26 Feb. 2010).

${ }^{102}$ Gachathi, F. N. and Eriksen, S., 'Gums and resins: The potential for supporting sustainable adaptation in Kenya's drylands', Climate and Development, vol. 3, no. 1 (Jan. 2011).
} 
conflict. These groups worked to alleviate poverty for other organization members by promoting livelihood diversification and developing microenterprises. For example, groups began to work on cultivating smallscale crops of grains and vegetables that could be quickly sold for a profit. This money was then deposited into communal savings accounts. As these savings increased from interest, membership costs and profits, group members took on microloans for larger enterprises including milk processing and poultry production. After a certain length of time, groups began to support emergency costs for the sick, elderly and other vulnerable community members. Money was reinvested into their communities through paying school fees for those in the most need, establishing scholarships and improving latrines and water points. The majority of group members highlighted the importance of these social networks in helping them through drought crises. The groups worked to assist members in adapting to changing environmental conditions, as well as holding 'peace meetings' and undertaking political advocacy work to respond to conflict. ${ }^{103}$ After male community members observed the success of the women's groups, they established a number of men's collective action groups. However, these groups did not work with the diversity of activities that the women's groups did, with the successful groups focusing mainly on livestock trading. ${ }^{104}$

In Somalia, climate change and conflict affect pastoralist and agropastoralist livelihoods and reshape gendered livelihood roles. ${ }^{105}$ Research shows that to cope with adverse livelihood conditions, different individuals in Somalia relied on social networks including families, gender-specific groups and clan members, among other networks, as well as livelihood diversification. Conflict in particular has compelled many women to take on the role of primary breadwinner within their households, while men participate less actively as livelihood earners. ${ }^{106}$ This is supported by other research highlighting how conflict and lack of livelihood resources contribute to challenges or the inability for men to fulfil their designated role as household providers. The traditional traits of masculinity include providing for their families, being a good husband and being a respected community member. However, conflict, limited economic opportunities and resources make these traits increasingly difficult to attain. ${ }^{107}$ This impacts both men and women, and inter-household dynamics. Men's vulnerability to SGBV in conflict can also impact their ability to consistently engage in livelihoods. Risk of forced recruitment, sex-selective massacre, revenge killings and vulnerability in situations where they are displaced from their clan network contribute to trauma and challenge their livelihoods. In some cases, if men could not find employment equivalent to their previous position-and clearly worthy of their social status-they may relegate their role as breadwinner

\footnotetext{
${ }^{103}$ Coppock, D. L. and Desta, S., 'Collective action, innovation, and wealth generation among settled pastoral women in northern Kenya', Rangeland Ecology \&t Management, vol. 66, no. 1 (Jan. 2013).

${ }^{104}$ Coppock and Desta (note 103).

105 Lwanga-Ntale, C. and Owino, B. O., 'Understanding vulnerability and resilience in Somalia', Jàmbá Journal of Disaster Risk Studies, vol. 12, no. 1 (14 Dec. 2020); and Eklöw, K. and Krampe, F., Climate-Related Security Risks and Peacebuilding in Somalia, Policy Paper no 53 (SIPRI: Stockholm, 2019).

106 Lwanga-Ntale and Owino (note 105).

${ }^{107}$ El-Bushra and Gardner (note 19); and Eklöw and Krampe (note 105).
} 
to their wives to avoid shame and to not fail the expectations of their fellow clansmen. The study indicates that women, on the other hand, were prepared to take on whatever roles necessary to ensure family survival. ${ }^{108}$ While these new roles can be empowering for some women, women still face structural disadvantages and political marginalization outside their households. Moreover, their new roles add to their significant household responsibilities. ${ }^{109}$ This dynamic can also contribute to domestic violence and stress within homes, if men try to reassert their dominance in households, or if women become frustrated by the financial dependency of their male partners. ${ }^{110}$ Family poverty and loss of income may also compel young men, and in some cases young women, to engage in violent and dangerous activities to supplement their income. ${ }^{111}$

In Liberia, conflict, climate change and insecurity of land tenure have challenged the successful production of food. Research was conducted on a sample of female farmers in three counties, many of whom became heads of household after losing their husbands or male family members in conflict and were solely responsible to provide for their families. This study noted that the ability to access a degree of credit and subsequent capacity to purchase seeds and other resources and to hire labour to help with farming was notable in promoting food security. In certain counties, women at the head of their households were left to defend their land from people trying to plant crops on it. These farmers were often more food secure than other surveyed counterparts, indicating that more productive land leads to more conflict. ${ }^{112}$

A study on the municipality of Maria la Baja in the Colombian Caribbean notes how climatic and seasonal pressures as well as paramilitary conflict linked to landgrabs and agricultural expansion have negatively affected the agrarian livelihoods of local communities. A wave of paramilitary violence in the 2000s forcibly displaced many farmers, causing men and women to take up jobs in urban areas. Since then, many families and individuals have returned to their original homes and livelihoods. The resources they returned to, however, had deteriorated due to conflict. Climate pressures increased this stress, with rainy seasons becoming shorter and less consistent. On return, women could be spatially constrained to their households, as male family members compelled them to remain inside fearing violence from armed conflict or due to their traditional ideas about women's roles in the household. This was a shift from the forests and areas in the countryside where women worked prior to the conflict. Men engaged in activities like agricultural employment and the production of cash crops. Women began to diversify their livelihoods within their domestic sphere, establishing food gardens, selling groceries, providing laundry services and working in livestock husbandry, among other activities. This diversification was crucial for improving livelihood stability. However with women's limited access to productive resources, minimal income and a disproportionate expectation

108 El-Bushra and Gardner (note 19).

109 El-Bushra and Gardner (note 19); and Lwanga-Ntale and Owino (note 105).

110 El-Bushra and Gardner (note 19).

${ }^{111}$ El-Bushra and Gardner (note 19).

112 Ahn, J. et al., 'Case studies of female-headed farms and households in Liberia: A comparative analysis of Grand Bassa, Lofa, and Nimba counties', The Journal of Agricultural Education and Extension, vol. 26, no. 1 (1 Jan. 2020). 
of care work, their own well-being and that of the broader household could be negatively impacted upon. ${ }^{113}$

In the Mindanao region of the Philippines, smallholder farmers are vulnerable to the compounding effects of climate change and conflict. For over four decades, a conflict over political control and cultural differences affected the region. ${ }^{114}$ One study highlights how women farmers-traditionally responsible for a wide array of activities, including managing home gardens, seed collection and storage, planting and harvesting-experience gender-specific risks stemming from culturally limited access to resources. While climate impacts influenced women to branch out into alternative livelihoods including microenterprises, limited access to resources and competing expectations surrounding their domestic role in the home was a continued source of stress. Poverty is exacerbated by extensive conflict and climate events and contributes to increasing income inequality for women. Female-headed smallholder households are at a higher risk of displacement due to conflict-in part because of poor customary rights to land and water resources and pressure to vacate their property. As a coping strategy, women tend to migrate to urban areas and overseas at higher rates than men. This contributes to a shift in traditional gender roles, with men at home taking on more responsibility for childcare. While women may migrate to gain extra income and support their families, this tactic is not without risks. If women farmers migrate to support their families, they are at risk of SGBV in their positions as labourers or domestic helpers, as well as facing risks of trafficking. ${ }^{115}$

In the culturally diverse Badakhshan province in the Pamir mountains between Afghanistan and Tajikistan, political instability and climatic variability are two factors that impact food security. Research indicates that local knowledge about soil, temperature, water, seasonality and local plants assists communities in maintaining food security. This knowledge is not uniform. It varies depending to gender, context and profession. Compared to men, women hold substantially more knowledge about different plants and livestock due to their gendered responsibilities. In both the Afghan and Tajik regions of the province, women are in charge of preparing land for cultivation in the spring, taking animals to pasture in the summer, harvesting wheat and preserving fruits and vegetables in the autumn and continuing to tend livestock in the winter. These activities are done alongside their other domestic and vocational responsibilities. ${ }^{116}$

In the Borana pastoralist communities of Ethiopia, climate change and conflict are among the stressors that impact livelihoods and food security. Household surveys indicate that women frequently ascribe more importance to climatic factors and pressures on rangeland resources as major stressors on their livelihoods. In contrast, men are more concerned with political

\footnotetext{
${ }^{113}$ Cely-Santos, M. and Hernández-Manrique, O. L., 'Fighting change: Interactive pressures, gender, and livelihood transformations in a contested region of the Colombian Caribbean', Geoforum, vol. 125 (Oct. 2021).

${ }^{114}$ Chandra, A. et al., 'Gendered vulnerabilities of smallholder farmers to climate change in conflict-prone areas: A case study from Mindanao, Philippines', Journal of Rural Studies, vol. 50 (Feb. 2017)

115 Chandra (note 114).

${ }^{116}$ Kassam (note 81).
} 
marginalization and governance issues. ${ }^{117}$ This dynamic is also supported by research in Mali, suggesting that traditional social roles and access to resources and decision making contribute to how men and women may perceive risks related to livelihood and insecurity. ${ }^{118}$ Women play a significant part in agricultural labour in Ethiopia (including pastoralism) but experience challenges in adapting to livelihood stressors due to limited access to resources including credit. In the Borana communities, research has noted how women are traditionally in charge of gathering water, firewood and grass. During dry seasons, the distance and time it takes to complete these tasks can be substantial. While the communities as a whole were impacted by drought, surveyed women highlighted that their traditional roles associated with these natural resources led to increased challenges for them in times of drought and livelihood stress. ${ }^{119}$ Women's adaptive capacity was additionally strained by increasing poverty, which negatively impacted access to resources traditionally shared through social networks in times of need. ${ }^{120}$ Through these social networks-or marro-women have traditionally shared resources including cash, labour and food to assist each other during drought. ${ }^{121}$ However, despite these challenges, other research further highlights how women in Borana communities diversify their livelihoods when faced with drought, conflict and other stressors. When drought leads to loss of cattle for men, women become breadwinners along with their husbands. Many women have engaged in petty trade, among other activities, within these circumstances. This shift in responsibilities leads to both increased income and changing gender dynamics. Women's increased financial independence contributed to an improved decision-making ability within their household, but it also led to greater workloads and in some cases tensions with their male relatives. ${ }^{122}$

\section{Gender and livelihood deterioration as factors in insecurity}

Comparatively far fewer articles identified in the literature review discussed how gender may be a variable that furthered insecurity within this pathway. An earlier review on gender and climate security and case study highlighting environmental deterioration in Nigeria highlight ways in which this may occur.

The earlier review on gender and climate security suggests that if climate change continues to increase inequalities, this may be a driver for women to join armed groups. The review noted that female mobilization into armed groups to counter inequalities and oppression could be observed among Maoist rebel groups in Nepal, the Kurdistan Workers' Party in Turkey and the People's War Group in India. ${ }^{123}$ If climate change increases inequalities

\footnotetext{
${ }^{117}$ Anbacha, A. E. and Kjosavik, D. J., 'Gendered perspectives of climatic and non-climatic stressors in Borana, southern Ethiopia', Journal of Arid Environments, vol. 166 (July 2019).

${ }^{118}$ Tobie, A., 'A fresh perspective on security concerns among Malian civil society', SIPRI Insights on Peace and Security no. 2017/2, July 2017; and Anbacha and Kjosavik (note 117).

${ }^{119}$ Anbacha and Kjosavik (note 117).

${ }^{120}$ Anbacha and Kjosavik (note 117).

${ }^{121}$ Anbacha, A. E. and Kjosavik, D. J., 'Borana women's indigenous social network-marro in building household food security: Case study from Ethiopia', Pastoralism, vol. 8, no. 1 (Dec. 2018).

122 Anbacha, A. E. and Kjosavik, D. J., 'Pastoral livelihood diversification and gender in Borana, Southern Ethiopia', Rangeland Ecology \& Management, vol. 79 (Nov. 2021).

${ }^{123}$ Ide et al. (note 4 ).
} 
and livelihood insecurity, it may 'accelerate gender-related risk factors for armed conflict'. ${ }^{124}$

A study on the Niger Delta suggests how gender and deteriorating environmental conditions may influence young men to engage in violent actions. In the Niger Delta within Nigeria, oil drilling has deteriorated traditional livelihoods including fishing and agriculture. ${ }^{125}$ Climate change poses an additional exacerbating stressor for livelihoods. ${ }^{126}$ Research highlights how environmental deterioration due to oil drilling has affected the ability of young men to achieve the 'socio-economic conditions for manhood', which include acting as a breadwinner and being financially independent. As a result, some young men join militant groups, both as a way of obtaining an income and expressing their grievances. ${ }^{127}$ Some interviewed militants discussed how they lacked the financial resources to marry or to bury relatives (as is expected of them) and engaged in violent activities to gain an income. ${ }^{128}$

\section{Migration and changing mobility}

Climate change is recognized as a factor that influences migration. ${ }^{129}$ Generally, research suggests it is more likely to facilitate temporary or intrastate migration, and rapid and slow-onset disasters can lead to different migration outcomes. While rapid-onset disasters can constrain migration by trapping populations, slow-onset climate disasters may prompt the decision to leave. ${ }^{130}$ Climate change is never the sole factor prompting migration; social, political and economic contexts all shape decisions to leave or remain. ${ }^{131}$ Migration may sometimes increase the risk of local-scale violence and conflict when social, political and economic influences move displaced migrants into the areas of other communities. ${ }^{132}$ Case studies on South East Asia, Uganda and Honduras provide examples of how gender influences risks and coping measures for different individuals related to the compound

\footnotetext{
${ }^{124}$ Ide et al. (note 4), p. 45.

125 Ashamole (note 47).

${ }^{126}$ Akinro, A. O., Opeyemi, D. A. and Ologunagba, I. B., 'Climate change and environmental degradation in the Niger Delta Region of Nigeria: Its vulnerability, impacts and possible mitigations', Research Journal of Applied Sciences, vol. 3, no. 3 (2008); and Hassan, I. et al., 'Potential impacts of climate change on extreme weather events in the Niger Delta part of Nigeria', Hydrology, vol. 7, no. 1 (21 Mar. 2020).

${ }^{127}$ Ashamole (note 47), p. 264.

${ }^{128}$ Ashamole (note 47).

${ }^{129}$ Kaczan, D. J. and Orgill-Meyer, J., 'The impact of climate change on migration: A synthesis of recent empirical insights', Climatic Change, vol. 158, no. 3-4 (Feb. 2020); Leighton, M., 'Drought, desertification and migration: Past experiences, predicted impacts and human rights issues', eds E. Piguet, A. Pécoud and P. De Guchteneire, Migration and Climate Change (UNESCO: Cambridge, 2011); Raleigh, C., Jordan, L. and Salehyan, I., Assessing the Impact of Climate Change on Migration and Conflict (World Bank: Washington, DC, 2008); Rigaud, K. K. et al., Groundswell : Preparing for Internal Climate Migration (World Bank: Washington, DC, 2018).

${ }^{130}$ Kaczan, D. J. and Orgill-Meyer, J., 'The impact of climate change on migration: A synthesis of recent empirical insights', Climatic Change, vol. 158, no. 3-4 (Feb. 2020).

${ }^{131}$ Barnett, J. and Chamberlain, N., 'Migration as climate change adaptation: Implications for the Pacific', ed. Burson, B., Climate Change and Migration South Pacific Perspectives (Institute of Policy Studies: Wellington, 2010); and Perch-Nielsen, S. L., Bättig, M. B. and Imboden, D., 'Exploring the link between climate change and migration', Climatic Change, vol. 91 no. 3-4, 2008.

132 Reuveny, R., 'Climate change-induced migration and violent conflict', Political Geography, vol. 26, no. 6 (Aug. 2007); and Mobjörk, Krampe and Tarif (note 1).
} 
impacts of climate change, migration and insecurity. Case studies on Nigeria and the sub-Saharan region discuss examples where gender influences insecurity related to climate change, migration or changing mobility.

\section{Gender, risk and resilience in contexts of climate change and migration}

Climate change may influence human trafficking in the fishing sector by contributing to a decline of already depleted fish stocks. In turn, this may contribute to the use of slave labour in fishing vessels trying to increase their catch. ${ }^{133}$ Research on trafficked fishermen in South East Asia highlights how gender influences the vulnerabilities and risks faced by the survivors. Men's decision to migrate to find improved economic opportunities after climate impacts affect their local livelihoods can also put them at risk of labour trafficking. ${ }^{134} \mathrm{~A}$ study on trafficked fishermen in the Mekong region found that they worked extreme hours (approximately 21 per day), had limited or no breaks, inadequate water and food supplies, minimal access to healthcare and were vulnerable to severe violence. Supervisors would sometimes threaten to kill workers, and the men could be sold between boats. Those that paid wages were given very little, while approximately 71 per cent of trafficked fishermen interviewed in the study reported being denied their promised income. ${ }^{135}$ The men reported physical and mental health concerns, as well as feelings of guilt and shame from the belief that they failed in their role as breadwinner. Some fisherman noted that they were shamed by family members upon their return home for failing to return with money or stigmatized for returning with tattoos. ${ }^{136}$ Similarly, another study on trafficked fisherman in Indonesia noted that they experienced severe violence and deprivation, as well as separation from their family. Upon returning to their families, their home life had a significant impact on their ability to recover and reintegrate after experiencing trafficking. The perceived 'failure' of the returning men to economically support their households was a cause of individual stress for the men and generated household tension. Family debts were incurred to support the men in the initial migration process and, again afterwards, to support the household while they were away. The inability to repay these debts led to tension between husbands and wives and, in some cases, with parents-in-law. Some men did not return home out of shame and guilt, instead remaining in urban areas to try to earn extra money for their families. In some cases, the extended period of absence also stressed social relationships with wives and children. ${ }^{137}$

The Bidi Bidi refugee settlement in Uganda became the world's largest refugee camp in 2017. During this time, hundreds of thousands of people crossed the border from South Sudan in the midst of severe famine and civil

\footnotetext{
133 Brown, D. et al., 'Modern slavery, environmental degradation and climate change: Fisheries, field, forests and factories', Environment and Planning E: Nature and Space, vol. 4, no. 2 (June 2021).

${ }^{134}$ International Organization for Migration (IOM), The Climate Change-Human Trafficking. Nexus (IOM Regional Office for Asia and the Pacific: Bangkok, 2016).

135 Pocock, N. S. et al., "'Because if we talk about health issues first, it is easier to talk about human trafficking"; findings from a mixed methods study on health needs and service provision among migrant and trafficked fishermen in the Mekong', Globalization and Health, vol. 14, no. 1 (Dec. 2018). ${ }^{136}$ Pocock (note 135).

${ }^{137}$ Surtees, R., 'At home: Family reintegration of trafficked Indonesian men', Anti-Trafficking Review, vol. 10 (2018).
} 
war. ${ }^{138}$ Within the camp, women and girls have been primarily responsible for gathering water and firewood. ${ }^{139}$ This corresponds with broader trends, with cultural norms in many localities placing this responsibility on women and girls. ${ }^{140}$ One study shows that ecological deterioration including deforestation has led to increased resource scarcity. Women and girls are put at heightened risk of SGBV on the increasingly lengthy journey to obtain these resources. In the camp itself, they are also at increased risk of exploitation, as they may be forced to engage in transactional sex to obtain food and resources for their households. ${ }^{141}$ Female-headed households in general can be at particular risk in the wake of disaster, should women be inhibited from accessing capital or resources to recover from the crisis. ${ }^{142}$

In Honduras, gender influences how both climate change and violence prompt migration choices for men and women. Research notes how severe violence due to gang activity in rural and urban areas incentivizes migration for men and women, although the perceived danger of the migration routes may influence differing paths for men and women. For example, more Honduran men than women migrate to the United States since it is a more dangerous route. Evidence indicates that women, on the other hand, are more likely to go to Spain. Both paths have the potential to influence and reconfigure traditional gendered socio-economic patterns in positive and negative ways. Women's employment in Spain is likely to be more profitable and longer term compared to men's short-term and cyclical work in the USA. An additional effect of men's short-term labour migration is a devaluing of education for men, as they may only have access to low-paying jobs requiring minimal skills. ${ }^{143}$ Climate change can further shape migration patterns due to its impacts on the coffee sector-Honduras' largest export. In times of stress in the coffee industry, men have migrated to the USA to cope with its economic impacts, while both women and men have increased migration to urban areas. ${ }^{144}$

\section{Gender, climate change, migration and insecurity}

How climate change and gender can influence migration and mobility can also contribute to the increased risks of violence and conflict. ${ }^{145}$ Evidence from East and West Africa suggests that conflict and climate change compel pastoral groups to change their traditional seasonal routes. ${ }^{146}$ When pastoralist groups move into the areas of agriculturalist groups they do not have past relationships with, this can sometimes lead into conflicts over resource access. ${ }^{147}$ Research on pastoral conflicts in different countries

\footnotetext{
${ }^{138} \mathrm{Hattem}, \mathrm{J.}$, 'Uganda at breaking point as Bidi Bidi becomes world's largest refugee camp', The Guardian, 3 Apr. 2017.

${ }^{139}$ Logie, C. H. et al., 'Exploring resource scarcity and contextual influences on wellbeing among young refugees in Bidi Bidi refugee settlement, Uganda: Findings from a qualitative study', Conflict and Health, vol.15, no. 1 (Dec. 2021).

${ }^{140}$ UN Water, 'Water and gender', [n.d.].

${ }^{141}$ Logie (note 139).

142 Hansson and Kinvall (note 67).

143 Myrttinen (note 50).

144 Myrttinen (note 50).

145 Ide et al. (note 4$)$.

146 van Baalen and Mobjörk (note 97); and Tarif (note 3).

147 Mobjörk, Krampe and Tarif (note 1); Njiru, B. N., 'Climate change, resource competition, and conflict amongst pastoral communities in Kenya', eds Scheffran, J. et al., Climate Change, Human
} 
suggests that men and women are affected by, and engage in, these conflicts in various ways. ${ }^{148}$ In South Sudan, Kenya and Uganda, cattle raiding is considered a mark of manhood for young men in pastoralist communities. Young men are required to pay a dowry, generally with cattle in order to marry. ${ }^{149}$ In Uganda, the presence of small arms exacerbates pastoral conflicts, and men are mainly involved in raiding. Women, who have limited formal rights to economic resources, encourage men to engage in the raids, as they benefit from the profit and resources brought by additional cattle. Women have also been involved in acquiring weapons for male relatives. ${ }^{150}$ Diminishing access to cattle compels women to branch out into other livelihoods including brewing and cereal banking, which can provide them with financial resources they did not previously have access to. ${ }^{151}$ Limited access to cattle also incentivizes poorer men to engage in raids due to social expectations surrounding manhood, as cattle is a form of bride wealth required for men to marry. While the shifting economic circumstances can in some cases create certain opportunities for women, they also face significant risks through negative coping mechanisms, or increased risk of violence when gathering resources. ${ }^{152}$

Research on conflict between migrants or IDPs and host communities in contexts affected by climate change has only minimally recognized gender. ${ }^{153}$ A study on the agricultural impacts of IDP influxes on host communities in Nigeria found dynamics could vary depending on whether IDPs were displaced due to conflict or natural disasters. In general, an influx of IDPs due to different shocks led to overall lower levels of agricultural productivity in host communities as a result of decreased productivity of land and labour. The research suggests that male and female-headed households may experience somewhat different effects. The research noted that femaleheaded households both had access to overall less land and produced less agricultural output then their male-headed counterparts. For both men and women working in agriculture in host communities, an influx of IDPs led to a decrease in daily wages due to the increase in labour supply. ${ }^{154}$

\section{Tactical considerations of armed groups}

Not only can climate change increase the risk of conflict, it can also be a factor in the tactical decision making of the leaders of combatant forces, both

Security and Violent Conflict (Springer: Berlin, 2012); Rigaud (note 129); Hegazi, F., Krampe, F. and Smith, E. S., Climate-Related Security Risks and Peacebuilding in Mali, SIPRI Policy Paper no. 60 (SIPRI: Stockholm, Apr. 2021).

${ }^{148}$ Ide et al. (note 4); Mkutu, K. A., 'Uganda: Pastoral conflict \& gender relations', Review of African Political Economy, vol. 35, no. 116 (June 2008); and Omolo (note 100).

${ }^{149}$ Ide et al. (note 4$)$.

${ }^{150}$ Mkutu (note 148).

${ }^{151}$ Mkutu (note 148).

152 Mkutu (note 148)

${ }^{153}$ De Juan, A., 'Long-term environmental change and geographical patterns of violence in Darfur, 2003-2005', Political Geography, vol. 45 (Mar. 2015); Koubi, V., 'Climate change and conflict', Annual Review of Political Science, vol. 22, no. 1 (11 May 2019); and Brzoska, M. and Fröhlich, C., 'Climate change, migration and violent conflict: Vulnerabilities, pathways and adaptation strategies', Migration and Development, vol. 5, no. 2 (3 May 2016).

${ }^{154}$ George, J. and Adelaja, A., 'Forced displacement and agriculture: Implications for host communities', Sustainability, vol. 13, no. 10 (20 May 2021). 
armed groups and government forces. Past research has noted that climate change can influence the tactics of armed groups in at least three primary ways: '(a) when they use coping strategies to reinforce group food security, (b) when they use the strain of climate-related impacts to boost recruitment, and (c) when they adapt behaviour to opportunistically capitalize on climate pressures. ${ }^{155}$

Compared to the other pathways, there is far less identified academic literature on the nexus between gender dynamics, climate change and armed group tactics. This corresponds with research on the pathways focusing on West Africa, which also notes a comparable dearth of literature on this pathway. ${ }^{156}$ Previous research on this pathway notes how armed groups may use the impacts of climate change to increase recruitment, but how gender factors into this recruitment has generally received little attention. ${ }^{157}$ A study on the Lake Chad Basin suggests how gender may influence the vulnerability of men and women to recruitment by armed groups in contexts affected by climate change. Research on Iraq suggests how men and women may be differently impacted by the compound effects of climate change and opportunistic behaviour of armed groups.

Research has found that in certain contexts, armed groups can capitalize on deteriorating livelihoods due to climate pressures to incentivize recruitment. ${ }^{158}$ In the Lake Chad Basin, climate pressures and violence are among the factors that impact livelihood security, increasing the ability of Boko Haram and the Islamic State and West Africa Province (ISWAP) group to recruit from at-risk populations. ${ }^{159}$ Research suggests that gender influences how young men in particular can be vulnerable to recruitment in this context, as livelihood deterioration inhibits traditional paths to manhood. Armed groups grant a salary, which allows young men to realize the conditions of manhood such as marrying and starting a family. ${ }^{160}$ Women may join these armed groups in search of social mobility, education or to be part of sociopolitical change. ${ }^{161}$ As mentioned previously, other research suggests that increasing gender inequalities and livelihood insecurity due to climate change may contribute to increased recruitment of women into armed groups, noting past patterns of increased female recruitment as a result of inequalities. ${ }^{162}$

Gender roles are likely to influence specific ways that individuals may be impacted by armed groups' manipulation of resources. For example, the Islamic State has been noted to weaponize water in Iraq, Syria and Yemen,

\footnotetext{
155 Mobjörk, Krampe and Tarif (note 1), p. 6.

156 Tarif (note 3).

${ }^{157}$ van Baalen and Mobjörk (note 97); Krampe and Tarif (note 1); Nordqvist and Krampe (note 3); King, M. D., 'The weaponization of water in Syria and Iraq', The Washington Quarterly, vol. 38, no. 4 (2 Oct. 2015).

${ }^{158}$ Mobjörk, Krampe and Tarif (note 1); Hegazi, Krampe and Smith (note 147); and UNDP Regional Bureau for Africa, Journey to Extremism in Africa:Drivers, Incentives and the Tipping Point for Recruitment (UNDP: New York, 2017).

${ }^{159}$ Vivekananda, J. et al., Shoring Up Stability: Addressing Climate and Fragility Risks in the Lake Chad Region (Adelphi: Berlin, 19 May 2019); and Owonikoko, S. B. and Momodu, J. A., 'Environmental degradation, livelihood, and the stability of Chad Basin Region', Small Wars \& Insurgencies, vol. 31, no. 6 (17 Aug. 2020).

160 Vivekananda et al. (note 159); and Owonikoko and Momodu (note 159).

${ }^{161}$ Vivekananda et al. (note 159).

162 Ide et al. (note 4).
} 
by cutting off water to populations, or putting them at risk of displacement due to flooding. ${ }^{163}$ In Iraq, climate change has compounded water scarcity caused by factors including weaponization by armed groups, and poor management and infrastructure. Gender shapes the impacts of and ability to cope with water-related stresses, with women and girls generally facing disproportionate impacts in this context related to gender-based needs and their role in household water management. ${ }^{164}$

\section{Elite exploitation and resource mismanagement}

Past research on climate insecurity pathways has noted that local-scale insecurity influenced by climate change impacts may be exacerbated by the exploitation of elite actors. Elite actors, which can be understood as 'individuals or groups with relative wealth, privilege, power or influence', may also capitalize on rapid-onset disasters to accrue power. Elite actors may also exploit vulnerable groups affected by livelihood insecurity and marginalization to recruit their support. ${ }^{165}$ Identified case studies within this review highlight slightly different dynamics. Research on the Niger Delta area of Nigeria highlights how men and women experience different risks and engage in resistance to elite exploitation of resources. Case studies from Bangladesh and Uganda underline how elite exploitation can occur as maladaptation, with subsequent gendered impacts.

\section{Risks and resistance to elite exploitation}

Broader research on environmental deterioration and resource scarcity in the Niger Delta provides nuance on the gendered impacts of elite exploitation of resource scarcity in the specific context. While not directly related to climate change, the research provides an example of how gender shaped responses by men and women to resource scarcity caused by elite exploitation of the environment, and how local level elites may have profited off of women's protests against the environmental exploitation. In the Niger Delta area of Nigeria, the exploitation of crude oil by government actors and multinational corporations has led to environmental degradation and the deterioration of traditional natural resource-dependent livelihoods of local populations. Research has also highlighted how the oil exploitation in the region contributes to global warming and acid rain, notably through gas flaring. ${ }^{166}$ A small number of primarily male elite actors benefited from oil

\footnotetext{
163 Gleick, P. H., 'Water as a weapon and casualty of armed conflict: A review of recent waterrelated violence in Iraq, Syria, and Yemen', WIREs Water, vol. 6, no. 4 (July 2019); and Eliasson, J., 'The rising pressure of global water shortages', Nature, vol. 517 (Jan. 2015).

${ }^{164}$ Kadry, S., 'Gender and water dynamics in Iraq: Towards inclusive and sustainable water responses', Water IsLife:Perspectives on WaterinMesopotamia (ElbarlamentCultures ofDemocracy: 2021).

165 Mobjörk, Krampe and Tarif (note 1), p. 7.

${ }^{166}$ Akinro, A. O., Opeyemi, D. A. and Ologunagba, I. B., 'Climate change and environmental degradation in the Niger Delta Region of Nigeria: Its vulnerability, impacts and possible mitigations', Research Journal of Applied Sciences, vol. 3, no. 3 (2008); Omofonmwan, S. I. and Odia, L. O., 'Oil exploitation and conflict in the Niger-Delta Region of Nigeria', Journal of Human Ecology, vol. 26, no. 1 (2009); Ubani, E. and Onyejekwe, I., 'Environmental impact analyses of gas flaring in the Niger Delta region of Nigeria', American Journal of Scientific and Industrial Research, vol. 4, no. 2 (Apr. 2013); and Ukeje, C., 'From Aba to Ugborodo: Gender identity and alternative discourse of
} 
exploitation at the expense of the majority of local communities. ${ }^{167}$ These circumstances have contributed to insecurity in the area and have led to conflict between local groups, violence against the corporations by local groups and local uprisings against the standing economic and political order. ${ }^{168}$ Research suggests that men and women were affected by and engaged in these dynamics in different ways. One study highlights how men who traditionally engaged in fishing or agriculture were unable to live up to traditional ideals of masculinity. Young men expressed frustration at their inability to be financially independent, act as a breadwinner and to be able to marry. ${ }^{169}$ The unemployment due to oil mining pushed some men to participate in violent or illicit activities to gain an income. ${ }^{170}$ Oil exploitation forced many women from their traditional livelihoods to find other sources of income, putting many at increased risk of sexual exploitation. ${ }^{171}$ Women also responded in varying ways, with some engaging in insurgent activity including intelligence gathering, gunrunning, as well as other forms of more domestic support. ${ }^{172}$ Many other women participated in predominantly female and comparatively peaceful protests against oil companies and government actors. Some research suggests that local leaders profited off these protests, either by accepting payment in return for suppressing them, or benefiting politically and financially from their success. ${ }^{173}$ Other research notes the different rationales of men and women for joining the insurgency. While male insurgents described fighting for freedom and social advancement among their reasons for joining, women were more prone to stating they fought for their children and the future of their communities. ${ }^{174}$ While the case study demonstrates women played into gender roles and stereotypes to resist this exploitation, it is also apparent that, despite their activism, they could be still marginalized from formal decision making and power. ${ }^{175}$

\section{Elite exploitation as maladaptation}

In different contexts, elite exploitation can occur as a negative effect of climate adaptation efforts-or maladaptation. Policies aimed at climate adaptation have the potential to contribute to conflict, should they fail to understand and address social issues and power structures. ${ }^{176}$ Instead of successfully helping individuals and communities adapt to the effects of climate change, inadequate adaptation policies can lead to negative effects, or maladaptation. ${ }^{177}$ Adaptation efforts in Bangladesh and Uganda have been

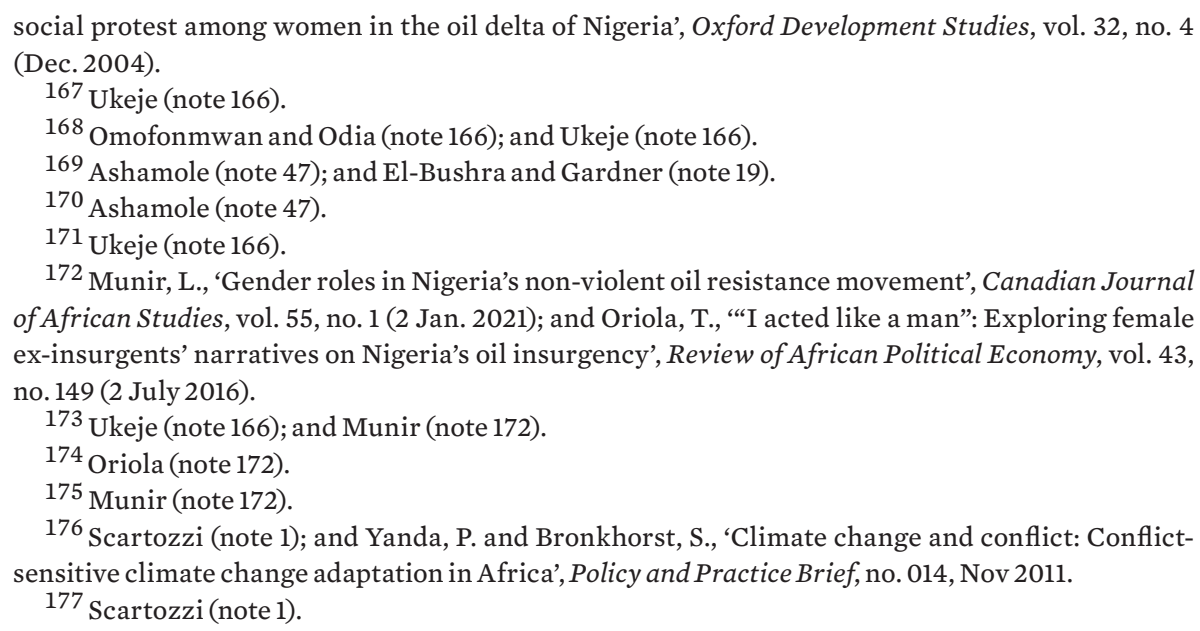


observed to benefit certain elite actors and further embed social inequalities in ways that can contribute to violence.

In Bangladesh, adaption efforts meant to assist coastal and vulnerable populations give way to land grabbing by elite actors. Aims of promoting afforestation led to an increased demand for agricultural land. The government designated protected coastal land within adaptation initiatives, with the subsequent effect of allowing elites with government ties to grab coastal land and bar others from access. ${ }^{178}$ Elites could capitalize on their knowledge of adaptation initiatives to grab land and then establish their control over it using small, hired militia or police forces. Elite control could marginalize different demographics of both men and women from participation in decision making regarding climate adaptation. Groups of women and other minorities were excluded on the basis of their ascribed identity. ${ }^{179}$ Lowerclass men were also disenfranchised in specific ways by elite control and maladaptation. Overlapping forms of gender and ethnic marginalization resulted in lower-class men with little to no claim over land compelled to do the majority of the physical work required by adaptation efforts, including digging canals and planting crops. ${ }^{180}$

Elite exploitation further influenced local coping mechanisms in Bangladesh, which can entrench pre-existing social inequalities and, in some cases, contribute to violence. Women who became displaced as a result of climate effects were compelled to raise household structures and construct new gardens due to gendered customs and expectations. Local elites could exploit displaced populations, providing access to land in exchange for cheap labour, or engaging them in their private security forces that could employ violent tactics to execute landgrabs. Patronage to elite actors was an inescapable part of climate adaptation for many displaced people and led to differing forms of marginalization for women and men. ${ }^{181}$

In Uganda, one study highlights how certain pastoral communities faced with the overlapping conditions of climate change and violence have increasingly been forced away from their traditional livelihoods. Instead, these communities engage in more diverse and sedentary activities in burgeoning towns and trading areas. ${ }^{182}$ This transition has led to various impacts for groups of women and men. Women began diversifying their livelihoods and taking on new economic roles. However, while additional economic roles may result in increased financial independence for women, women do not own their means of production. Increased sedentarization has also privileged male elite actors and allowed them to accumulate wealth and assets. These elite patriarchs accumulate wealth both through violent dispossession of cattle, as well as exploiting the labour of poorer families who work on the land they control. The process of livelihood diversification and

\footnotetext{
${ }^{178}$ Sovacool, B. K., 'Bamboo beating bandits: Conflict, inequality, and vulnerability in the political ecology of climate change adaptation in Bangladesh', World Development, vol. 102 (Feb. 2018).

${ }^{179}$ Sovacool (note 178).

${ }^{180}$ Sovacool (note 178).

181 Sovacool (note 178)

${ }^{182}$ Caravani, M., "'De-pastoralisation” in Uganda's northeast: From livelihoods diversification to social differentiation', The Journal of Peasant Studies, vol. 46, no. 7 (10 Nov. 2019).
} 
sedentarization resulting from climate change and conflict thus contributed to increasing inequalities within communities. ${ }^{183}$

\section{Assessment of findlings}

This paper has explored a selection of academic literature on respective intersections of gender, climate change and the four identified pathway themes: (a) livelihood deterioration, (b) migration and changing mobility, (c) tactical considerations of armed groups and (d) elite exploitation and resource mismanagement. When evaluated against existing research on pathways between climate change and insecurity, certain gaps are apparent.

\section{Geographic scope}

Relevant literature on the gender dimensions of the different pathways encompasses a much broader geographical scope than the earlier studies, that respectively target East Africa, South and South East Asia, and West Africa. Literature focusing on gender included in this review primarily covers rural areas, and none of this literature targets countries in the Global North. This possibly reflects both the state of existing research on climate and conflict, as well as on gender and climate change. Climate and conflict literature has been critiqued for predominantly focusing on certain regions in the Global South, which may correspond with the available data on conflict and climate. ${ }^{184}$ Past literature on gender and climate change has also been critiqued for disproportionately focusing on women in the Global South. ${ }^{185}$

\section{Livelihood deterioration}

Across the four pathways the amount of available literature on the gender dimensions is inconsistent. Substantially more research was found on gender dimensions of livelihood deterioration and insecurity. However, within that research, the literature leans more towards research focused on women. This again may reflect the pre-existing gaps in scholarship on gender and climate. ${ }^{186} \mathrm{Men}$ and boys with resource-dependent livelihoods receive significantly less focus than women within the identified literature. Different studies in this pathway also highlight women's informal responses and the potential for men to engage in violent activities when faced with no other alternative income sources. ${ }^{187}$ Fewer articles highlighted the reverse-peaceful ways of addressing the issue for men and, or engagement in violent activities by women.

\footnotetext{
183 Caravani (note 182).

${ }^{184}$ Adams, C. et al., 'Sampling bias in climate-conflict research', Nature Climate Change, vol. 8, no. 3 (Mar. 2018)

${ }^{185}$ Lau (note 82); MacGregor, S., “'Gender and climate change”: From impacts to discourses', Journal of the Indian Ocean Region, vol. 6, no. 2 (Dec. 2010); and Arora-Jonsson, S., 'Virtue and vulnerability: Discourses on women, gender and climate change', Global Environmental Change, vol. 21, no. 2 (May 2011).

${ }^{186} \mathrm{Lau}$ (note 82); MacGregor (note 185); and Arora-Jonsson (note 185).

187 Ibnouf (note 98); Yongo, Abila and Lwenya (note 101) Coppock and Desta (note 103); LwangaNtale and Owino (note 105); El-Bushra and Gardner (note 19); and Kassam (note 81).
} 
Past SIPRI research on the livelihood deterioration pathway highlights how the impacts of livelihood deterioration due to climate change may lead to conflict through contributing to increased marginalization and grievances, or increasing the risk that people may ensure resource access through violence. ${ }^{188}$ As the discussion on livelihood deterioration within this research highlighted, gender is not only a variable that may influence how this pathway leads to conflict, but it may also mitigate it. The case study from Nigeria, while not explicitly focused on climate change, suggests the role that masculinity may play in shaping grievances related to livelihood deterioration. ${ }^{189}$ Climate change's impact on increased inequalities and food insecurity may also contribute to women's engagement in armed groups. ${ }^{190}$ The discussed case studies on Western Sudan (pre-2011), Kenya, Somalia, Liberia, Colombian Caribbean, the Philippines, the Pamir Mountains between Tajikistan and Afghanistan, and Ethiopia highlight the crucial and innovative roles that women play in adapting to climate change and insecurity, and assisting their broader communities.

\section{Migration}

In regards to the migration pathway, the discussed academic literature points to gendered risks and experiences felt by male and female genders when faced with migration or displacement related to climate change and conflict. ${ }^{191}$ It also highlights how gender roles, migration related to environmental factors can influence different dynamics with the potential to contribute to conflict, including violence between pastoralist and farming communities, and relationships between IDPs and host communities. ${ }^{192}$ This further underlines the need to prioritize gender within work on climate and security.

\section{Tactical considerations}

In contrast to the other three pathways, identified literature on gender, climate change and tactical considerations of armed groups is comparatively sparse. The available literature included in this review generally focuses on how gender influences the recruitment of men and women into armed groups, or the risks felt by women as a result of armed group actions. ${ }^{193}$ More research into how gender and climate change shape armed group recruitment is necessary, as is research on how gender and climate change shape vulnerabilities of different groups of men and women due to armed group tactics. Future research on this pathway should note the tendency of mainstream gender and security policy to assume men's implicit participation as combatants and ignore both men's vulnerability as well as women's potential engagement as armed actors. ${ }^{194}$ Of note is one article

\footnotetext{
188 Mobjörk, Krampe and Tarif (note 1); and Nordqvist and Krampe (note 3).

${ }^{189}$ Ashamole (note 47).

${ }^{190}$ Ide et al. (note 4).

${ }^{191}$ Pocock (note 135); Surtees (note 137); Logie (note 139); and Myrttinen (note 34).

192 Ide et al. (note 4); Mkutu (note 148); and George and Adelaja (note 154).

193 Kadry (note 164); and Vivekananda et al. (note 159).

194 Myrttinen (note 34).
} 
that questions whether climate change will increase female recruitment as inequalities are exacerbated. ${ }^{195}$

\section{Elite exploitation}

Finally, examining the gender dimensions of the last pathway, elite exploitation, provides nuances to research that has previously examined group dynamics. The case studies suggest how gender dynamics may contribute to violence within this pathway, as well as shape how different individuals are affected by elite exploitation. ${ }^{196}$ The case studies in this pathway also highlight how if gender is not factored into policies aimed at addressing climate change, this can in some cases lead to increased inequalities and vulnerabilities for different groups of men and women. ${ }^{197}$

\section{Implications for research and policy}

This SIPRI Insights paper examined literature on the gender dimensions of climate insecurity pathways, highlighting certain ways in which gender can affect these pathways and lead to risks for different individuals in their midst. To address and mitigate climate-related security risks, it is necessary to ensure the equal leadership of all genders and consider the interlinked dynamics between them. The equal and meaningful leadership of women in addressing these issues corresponds with positive effects for those in their households and broader communities. ${ }^{198}$ Failing to recognize genderspecific impacts experienced by men and women can negatively impact their human security on an individual level and create cascading impacts for those around them. ${ }^{199}$ Yet, to date, relevant research and policy related to gender, climate change and security has not equally and critically focused on the needs and participation of all genders.

The case studies discussed in this report provide further evidence of the crucial role that women play in addressing climate change and insecurity within their communities. While women are often sidelined from formal decision making on these issues, the case studies demonstrate how they use social networks, as well as gender-specific local knowledge surrounding their environment to help ensure community resilience in times of livelihood insecurity. ${ }^{200}$ To improve individual and community resilience to climate change and insecurity, women should have equal and meaningful participation in formal decision making around these issues. ${ }^{201}$

As discussed in section II, the WPS agenda and the UNFCCC are two frameworks addressing the respective intersections of gender and security, and climate change and gender. They have also both been proposed as two potential frameworks capable of addressing the nexus of gender, climate

\footnotetext{
195 See Ide et al. (note 4).

196 Ashamole (note 47); Ukeje (note 166); and Sovacool (note 178).

197 UNEP (note 5).

198 Coomaraswamy (note 10); and Tanyag and True (note 71).

${ }^{199}$ UNEP (note 5).

200 Ibnouf (note 98); Yongo, Abila and Lwenya (note 101); Coppock and Desta (note 103); LwangaNtale and Owino (note 105); Kassam (note 81); Anbacha and Kjosavik (notes 121 and 122).

201 Tanyag and True (note 71).
} 
change and security. ${ }^{202}$ However, within these two frameworks, little attention is paid to the specific gendered risks and needs felt by men or people with other gender identities. ${ }^{203}$ Within the resolutions of the WPS agenda, the only mention of climate change is found briefly in the eighth resolution, UN Security Council Resolution 2242. ${ }^{204}$ Of the publicly available WPS National Action Plans (NAPs) in English-blueprints for states to use in implementing the WPS agenda-none directly reference men and boys or other gender identities within objectives or actions focusing on climate change as of $2020 .{ }^{205}$ As section II and the case studies in section III of this paper illustrate, there is a need for research and policy to critically pay attention to how gender influences vulnerabilities and actions of different groups of men in situations affected by climate change and insecurity. To not do so is not only a problem from a human rights perspective, but it can have negative impacts on women's human security, household dynamics and broader insecurity. ${ }^{206}$ Further, the case studies also highlight how climate change and conflict can reshape gender relations for men and women. In some cases, this can be positive for improving gender equality, but in other cases it can lead to individual and household stress. ${ }^{207}$ Frameworks or tools that address the nexus between gender, climate change and security should recognize the relational aspect of gender to understand how the experiences of men and women can have broader impacts on their households and communities. Further, in some cases, studies suggested women could take a more combative role in furthering insecurity indirectly related to climate change. ${ }^{208}$ Noting the WPS agenda's historic tendency not to focus on women's role in instigating violence, this is also something that frameworks addressing gender, climate and security should recognize. ${ }^{209}$

Moving forward, researchers and policymakers who seek to address gender, climate and security should increase their focus on ensuring the equal and meaningful participation of diverse groups of women in formal leadership positions. Simultaneously, increased attention needs to be paid by research and policy to the specific needs and equal participation of diverse groups of people with other gender identities, recognizing the unique risks they may face due to climate change and insecurity. ${ }^{210}$

\footnotetext{
202 Smith, Olosky and Grossman Fernandez (note 7); and UNEP (note 5).

203 UNFCCC (note 93); UNEP (note 5); Smith, Olosky and Grossman Fernandez (note 7); and Myrttinen (note 34).

${ }^{204}$ Smith (note 5).

${ }^{205}$ Smith (note 5).

${ }^{206}$ Christian (note 14); El-Bushra (note 19); El-Bushra and Gardner (note 19); Surtees (note 137); Vivekananda et al. (note 159); and Myrttinen (note 34).

207 Anbacha and Kjosavik (note 122); and El-Bushra and Gardner (note 19).

${ }^{208}$ Ide et al. (note 4).

${ }^{209}$ Puechguirbal (note 19).

${ }^{210}$ Gaillard, J. C. et al., 'Beyond men and women: A critical perspective on gender and disaster', Disasters, vol. 41, no. 3 (July 2017); and Hagen, J. J., 'Queering women, peace and security', International Affairs, vol. 92, no. 2 (Mar. 2016).
} 
SIPRI is an independent international institute dedicated to research into conflict, armaments, arms control and disarmament. Established in 1966, SIPRI provides data, analysis and recommendations, based on open sources, to policymakers, researchers, media and the interested public.

\section{GOVERNING BOARD}

Ambassador Jan Eliasson, Chair (Sweden)

Ambassador Chan Heng Chee (Singapore)

Jean-Marie Guéhenno (France)

Dr Radha Kumar (India)

Dr Patricia Lewis (Ireland/ United Kingdom)

Dr Jessica Tuchman Mathews

(United States)

Dr Feodor Voitolovsky (Russia)

\section{DIRECTOR}

Dan Smith (United Kingdom)
SIPRI INSIGHTS ON PEACE AND SECURITY NO. 2022/4

\section{GENDER DIMENSIONS OF CLIMATE INSECURITY}

ELIZABETH S. SMITH

\section{CONTENTS}

I. Introduction

Box 1. Methodology 2

II. Gender and climate security: Gaps and concepts 2 Gender and security 3 Gender and climate 7

Gender and climate security 13

Box 2. Understanding gender 3

III. Climate insecurity pathways 14

Livelihood deterioration $\quad 14$

Migration and changing mobility $\quad 20$

Tactical considerations of armed groups 23

Elite exploitation and resource mismanagement $\quad 25$

IV. Assessment of findings 28

Geographic scope $\quad 28$

Livelihood deterioration $\quad 28$

Migration $\quad 29$

Tactical considerations $\quad 29$

Elite exploitation $\quad 30$

V. Implications for research and policy 30

\section{ABOUT THE AUTHOR}

Elizabeth S. Smith (United States) is a Research Assistant with the SIPRI Climate Change and Risk Programme. Her research focuses on climate change, peacebuilding and gender.

\section{sipri}

STOCKHOLM INTERNATIONAL PEACE RESEARCH INSTITUTE

Signalistgatan 9

SE-169 72 Solna, Sweden

Telephone: +4686559700

Email:sipri@sipri.org

Internet: www.sipri.org 